\section{Designing parametric rhizomes in architectural space}

Gülru MUTLU TUNCA1 ${ }^{1}$, ORCID: 0000-0003-4945-8242

Güler Ufuk DEMİRAŞ², ORCID: 0000-0001-6235-6836

\begin{abstract}
The technological developments in the world present a challenge to design studio students and educators alike since the incorporation of computeraided design software into design education has become a necessity. This paper focuses on the 2019-2020 Spring Semester of INAR 302 Interior Design Studio IV at Çankaya University, which is a parametric design studio where students are encouraged to experiment and utilize computerbased form-finding strategies, concentrating on the interior space. The rhizome concept of Deleuze and Guattari is reinterpreted by Studio 302 as a design methodology, allowing students to experience the unorthodoxy of space-user dialectics in the inner voids of the parametric forms over the term project of re-functioning a part of Ulus Square Office Complex as a city hotel with a futuristic extension. The study examines and evaluates the students' works, which derive conceptual ideas from the formal analyses of ceramic artworks in the Anafartalar Bazaar and environmental analyses of the historic site, transforming them into the parameters of futuristic architectural form and diverse rhizome interpretations. The findings indicate that students' reinterpretations of "variations" in the ceramic artworks uncover multifaceted outcomes of digital design strategies, maintaining diverse rhizomatic progress, which synchronically determines and is determined by the functional mutations.
\end{abstract}

\section{Highlights}

- New technologies mandate the incorporation of computer-aided design into the design studio education.

- Parametric design strategies, amplifying rhizomatic conceptualization and transformation aid students to capture a solid design language and to acquire a new vision towards interior space design.

- Emulating artworks as the source of inspiration has become a practical basis for form-finding experiments.

\section{Keywords}

interior architecture; design studio education; parametric design; rhizomatic conception; computeraided design; metamorphosis

\section{Article Information}

Received:

29.04.2021

Received in Revised Form:

07.07.2021

Accepted:

07.07.2021

Available Online:

29.07.2021

\section{Article Category}

Research Article

\section{Contact}

1. Çankaya University, Faculty of Architecture, Ankara, Turkey gulru@cankaya.edu.tr

2. Çankaya University, Faculty of Architecture, Ankara, Turkey udemirbas@cankaya.edu.tr 


\section{INTRODUCTION}

The rapid technological developments and social changes of the past two decades have shown their effects in all design-dominated areas and thus presented complex challenges for architectural practice and design studio education. As a realm where practice and theory overlap and sometimes contradict, the design studios mediate students to learn and practice new skills, debates, visualization, and presentation techniques; learn and practice a new graphic and verbal language, as Schön (1984) claimed. They teach to "think architecturally," as Ledewitz (1985) explained, referring "to a particular domain of problems and solutions that characterize, and are fundamental to, professional performance" (Demirbaş, Demirkan, 2003, p. 2). As the advancements in computer technologies and their practice in all fields of design have brought along the necessity of learning and incorporating computer-aided design programs into the design studio education, the academicians conducting a design studio started to reconfigure studio setups adopting new tutoring strategies for the creative coalescing of digital design work with new possibilities. Nowadays, embracing the complexity of contemporary architectural methods, tutoring strategies necessitate retooling its infrastructure by digital technology and encouraging students to engage with algorithmic-parametric approaches in architectural design.

In the 1990s, the creative integration of the computer as a design tool by practitioners such as Zaha Hadid, Frank Gehry, and Greg Lynn stipulated the schools of architecture like MIT, Columbia, UCLA, and SCI-Arc to refurbish their technological infrastructure and teaching methods. As the computers facilitated the creation of complex shapes, biomorphic forms, and continuous surfaces, the early architectural practice, based on digital technology, produced "new fluid modeling plasticity," which remarkably fascinated the architecture students of the day. Since then, the design culture continued to change and adapt simultaneously, and "what was once a radical experiment became mainstream as other schools followed the lead of the early adopters" (Allen, 2012). In architectural schools today, academicians address two complementary directions concerning digital work. First accepts digital design expertise as the ultimate architectural skill to teach students and focuses on the computer's strategic and operative potential. Incorporating digital technologies into form-finding processes and implementation strategies restructure the logic of design processes. The second direction explores sophisticated applied research in computation and concentrates on scripting, robotics, and parametric design, particularly at the Ph.D. level. The believers of this direction go beyond the dedication of the ones in the first direction. They can write their codes 
besides that of the interface or apply ready-made plug-ins distributed on the internet as open-source material, which allow adaptive variations and continuous differentiation for the systematic and dynamic generation of the form (Schumacher, 2008). The thrust of this research is practical and result-oriented, engaged with construction logistics and material performance functioning to optimize the design by analyzing quantitative data on wind, environmental conditions, building height, width, texture, scale, topography, light, number of users, and energy requirements. (Allen, 2012) Besides, some codes serve to design complex architectural forms' structural systems and help develop construction details three-dimensionally. However, in schools of Turkey, incorporating parametric design into the design studios is a relatively new endeavor of architectural departments; it is even rarer for interior architecture departments. Parametric design has only entered interior architecture programs in the last five years. A couple of examples to interior architecture departments that incorporate Parametric design education into the syllabus of the design courses are Çankaya University, Yaşar University, Fatih Sultan Mehmet Vakıf University, İzmir University of Economics, Başkent University (Şekerci, Yıldız, 2020).

This study concentrates on a particular studio experience conducted at Çankaya University in the 2019-2020 Spring Semester. INAR 302 Interior Design Studio IV (Studio 302) is a parametric design studio where students are encouraged to experiment and utilize the computer-based formfinding strategies, yet with a particular concentration on the interior space. The rhizome concept of Deleuze and Guattari is reinterpreted by Studio 302 as a design methodology, allowing students to experience the unorthodoxy of space-user dialectics in the inner voids of parametric forms. The study aims to analyze and evaluate this design studio that has incorporated the computer-aided design into its syllabus stage by stage. Designing a parametric shell for a historic building, problematized by the challenge of keeping the embedded values of the architectural structure and artworks within, the studio experience under examination reveals the phases of familiarizing students with new design approaches. This study objectively discusses the studio outcomes to justify each stage's operativeness, by analyzing selected student projects and exploring the instrumentality of tutoring strategies for the creative synthesis of digital design work into interior architectural education.

The Department of Interior Architecture at Çankaya University envisioned its curriculum to equip students with adequate knowledge and skills necessary for their design studio experience, offered every semester. As an integral part of a chain, each studio, a prerequisite for the latter, contains diverse topics, specified according to function variety, architectural program complexity, and scale differences from small to extra-large. In these studios, as also mentioned by Oxman, the students assimilate the design thinking process to some extent and learn to develop creative solutions to architectural problems (Oxman, 2017, pp 4-59). As the form-finding and presentation methods shift from hand drawing to computer-based techniques, the third-year design studios require a different set of skills. The students encounter computer-aided design applications for the first time in their fifth semester and improve their skills in Studio 302, offered in the sixth semester. To fulfill the requirements of Studio 302, the students must have sufficient knowledge to succeed in the digital design studio as the result of the theoretical and applied courses they have taken in the first two academic years. The condition for Çankaya University students is quite the contrary. They often find themselves ignorant about the topic and feel compelled to go on an uncanny adventure. 
The technical information taught by second-year computer courses covers the fundamentals of CAD applications. This education neither fulfills the requirements of computer-based design studios nor the generative design applications. Therefore, computer-based design studios, such as Studio 302, become a challenge for students who cannot improve their computer skills unless they take elective courses on 3D modeling software. To overcome this challenge and boost student confidence, the instructors give lectures about software features during studio hours and implement teaching strategies for enhancing their sensibility and awareness of the subject. The design process is initiated with the analysis of environmental, architectural, and urban context to unveil the complex web of relations for deriving form-finding parameters adapted to the rhizomatic evolution of interior space. Studio 302 employs a dual-contextual approach that implies both the site-specific design of digital forms, diversified within the framework of urban and environmental factors on the architectural scale, and the metamorphosis of parametric forms concerning functional requirements on the interior architectural scale. Due to this duality in meaning, formfinding experiments examine generic morphologies resulting from contextual differences on architectural and interior architectural levels.

\section{FROM CONCEPT TO METHOD: RHIZOMATIC EVOLUTION}

Parametricism refers to generic design via algorithms (Schumacher, 2008; 2009). The parametric design process requires an algorithmic thinking system based on variables and evolvable parameters, measures, and rules. (Jabi, 2013; Woodbury, 2010). As the term reminds of the futuristic building typology of contemporary avant-garde architecture (See Fraser, 2016; Davis, 2014), the students mostly associate parametric design with the organic forms of Zaha Hadid. Within the framework of third-year Interior Design Studio, on the contrary, parametric production evolves into a rhizomatic act, grounded on the heterogeneity of trans-disciplinary connections between semiotic chains, social and cultural factors, urban infrastructure, and environmental conditions. The instructors compel students to combine such interdisciplinary heterogeneity with extensive functional requirements of architectural programs and physical/climatic problems of architectural sites. The main focus of Studio 302 is this heterogeneity, generating the metamorphosis of parametric rhizomes with adaptable natures in interior space. The principal characteristics of a rhizome are, according to the 1949 article on A Thousand Plateaus of Gilles Deleuze and Felix Guattari:

$[\mathrm{u}]$ nlike trees or their roots, the rhizome connects any point to any other point, and its traits are not necessarily linked to traits of the same nature; it brings into play very different regimes of signs, and even nonsign states. The rhizome is reducible to neither the One or the multiple. It is not the One that becomes Two or even directly three, four, five etc. It is not a multiple derived from the one, or to which one is added $(n+1)$. It is comprised not of units but of dimensions, or rather directions in motion. It has neither beginning nor end, but always a middle (milieu) from which it grows and which it overspills. It constitutes linear multiplicities with $\mathrm{n}$ dimensions having neither subject nor object, which can be laid out on a plane of inconsistency, and from which the one is always subtracted (n-1). When a multiplicity of this kind changes dimension, it necessarily changes in nature as well, undergoes a metamorphosis. (Deleuze \& Guattari, 1987, p. 21) 
Entitled "Parametric Rhizomes in Architectural Space," the syllabus of Studio 302 elaborates the interpretation of rhizomé, conceptualized by Deleuze and Guattari as an architectural design method employed by parametric means. Generally, Studio 302 deals with re-functioning an existing building as a museum, office headquarter, hotel, hostel, guest house, shopping center, department store, congress and cultural center, youth center, or center for kids, and encourages students to develop interior architectural solutions with this rhizomatic methodology. Preliminary research and concept/form creation, parametric design of architectural form and interiors, and detailed design of selected spaces are the three stages of an immersive and multidimensional studio program designed to direct, empower, and encourage students.

The first stage begins with preliminary research on the architectural program, building codes, and fire-safety regulations related to the proposed functional use. For the SWOT analysis of the immediate environment, the students create diagrams establishing interconnections between the interior space and the urban fabric. The analytical survey of paths, landmarks, nodes, edges, and urban behavioral patterns, which turns into a dialogue, oscillating at the intersection of discussions on the urban, architectural, and interior scales, aims to evaluate the site/program-specific inspirations as the inputs of form-finding experiments. As the aim is to inspire the students to develop problem-specific solutions, considering the functional needs of users, form-finding experiments also include parameters related to user experience and behavioral patterns. Utilizing the potentials of three-dimensional modeling software of the responsive computer-aided design, the preliminary nature of form undergoes a metamorphosis as parametric rhizomes according to shifting functions in the architectural space. Several academicians, teaching and practicing digital design approaches, might condemn such an analytical beginning as conventional. However, the instructors of Studio 302 consciously conceive such a traditional start for decreasing the anxiety of inexperienced and unconfident students and prepare them for their uncanny adventure in a new and manipulative digital domain. Students become familiar with the notion of parametric design throughout the first stage, yet with a fundamental difference. They experience the parametric shell inside-out with an emphasis on the interior space. Compelling students to interpret the parameters of environmental factors when generating rhizomes, Studio 302 challenges them with a dialectical conflict of designing a parametric extension to the Cartesian space. The existing building, given to the students for re-functioning, is selected among structures that have standard column spacing depending on the structural requirements of either concrete or steel systems. The studio assignments aim to provoke students to design the inner voids of parametric forms with transfigured rhizomes that destroy the Cartesian grid. According to adjacencies, the second stage requires students to develop vertical and horizontal schemes of allocation and their interrelation and work on two-dimensional plans/sections and three-dimensional models. One-on-one critiques, conducted every studio day, help students improve their proposals to a more solid-state. At the end of the second stage, the instructors deliver their latest remarks on the overall plan organization and form-finding experiments. Having elucidated the latest critiques, the students finalize the plan allocation and form generation process. The third stage is when students concentrate on the detailed design of selected spaces in the third stage. They develop the 3D model of particular interior spaces in detail, focusing on ceiling-wall, wall-floor conjunctions, as assigned by the syllabus, and make decisions on lighting elements, furniture, colors, all finishing materials, and video-rendered with real-time textures. They delineate the codes and technical features of the 
selected materials, in addition to brief information about the manufacturer and designers of fixtures. They are also responsible for the fire and HVAC systems proposals (sprinklers, fire detectors, air ducts, and diffusers). Such detailed work on each architectural space requires extra attention and problem-solving capability of the students, thus upskills their ability to solve advanced details.

Providing all the requirements for ultimate success to some extent, Studio 302 at Çankaya University experiments with parametric design approaches to solve problems on complex identities in interior space and motivate students to internalize the design act of contemporary architectural practice. In addition to the proficiency in implementing digital technologies for the designing process and its representation, the students acquire skills to deal with complex architectural programs. For the last five years, Studio 302 instructed projects such as techno-polis, department store, escape-hotel, museum, cultural center, and city hotel.

\section{INSPIRATIONS, RULES, PATTERNS AS PARAMETRIC INPUTS: THE PROBLEM OF PARAMETRIC DESIGN AT A HISTORICAL SITE}

This study concentrates on the student projects designed for the spring semester of the 2019-2020 education year, under the title "CITY HOTEL ANKARA: Parametric Rhizomes in Accommodation Spaces with Futuristic Extensions." The syllabus of the term project assigned the re-functioning of the middle block in Ulus Square Office Complex (Fig.1) as a city hotel with a futuristic extension that would function as a social hub in close relation to city life. Since designing a hotel requires detailed research on its architectural requirements, students developed an architectural program that included hotel rooms, meeting areas, fitness and spa areas, restaurants/cafes, and administrative offices. The analysis of the urban behavioral patterns, walking paths, the nodes of assembly areas, the boundaries, limits, edges of the close-environment, thus the analytical maps on environmental analyses unveiled the complex list of parameters to be translated into algorithms of form-finding experiments. (Fig.2) Students contemplated the thresholds and atmospheres encountered through the movements and considered space organization and circulation concerning fire safety, universal design, and building code regulations.

All requirements were assigned to provoke students to articulate their design scenarios for the accommodation facility considering the social and cultural aspects of the historical site. As the fictional design scenario of Studio 302 assumed, any futuristic architectural form erected at that particular point would emulate to become an architectural landmark for Ulus district, transforming the city life and rewriting the cultural codes of collective memory. The students were independent to develop innovative architectural concepts yet provoked to analyze the positive and negative consequences of their formal inference concerning public life, urban behavioral patterns, and sociocultural factors. Genius Loci of Ulus district characterized the student decisions on the design principles of parametric rhizomes and their derivation into futuristic extensions. This decisionmaking process led to severe conceptual clashes between the architectural significance of the existing building, social activity habits, cultural codes, and collective memory of the historical site, and the futuristic form that rejected all. 


\section{Gર1)}

Vol. 4, No. 2, 202I, I63-I92 / Cilt 4, Sayı 2, 202I, I63-I92 / DOI: 10.37246/grid.929577
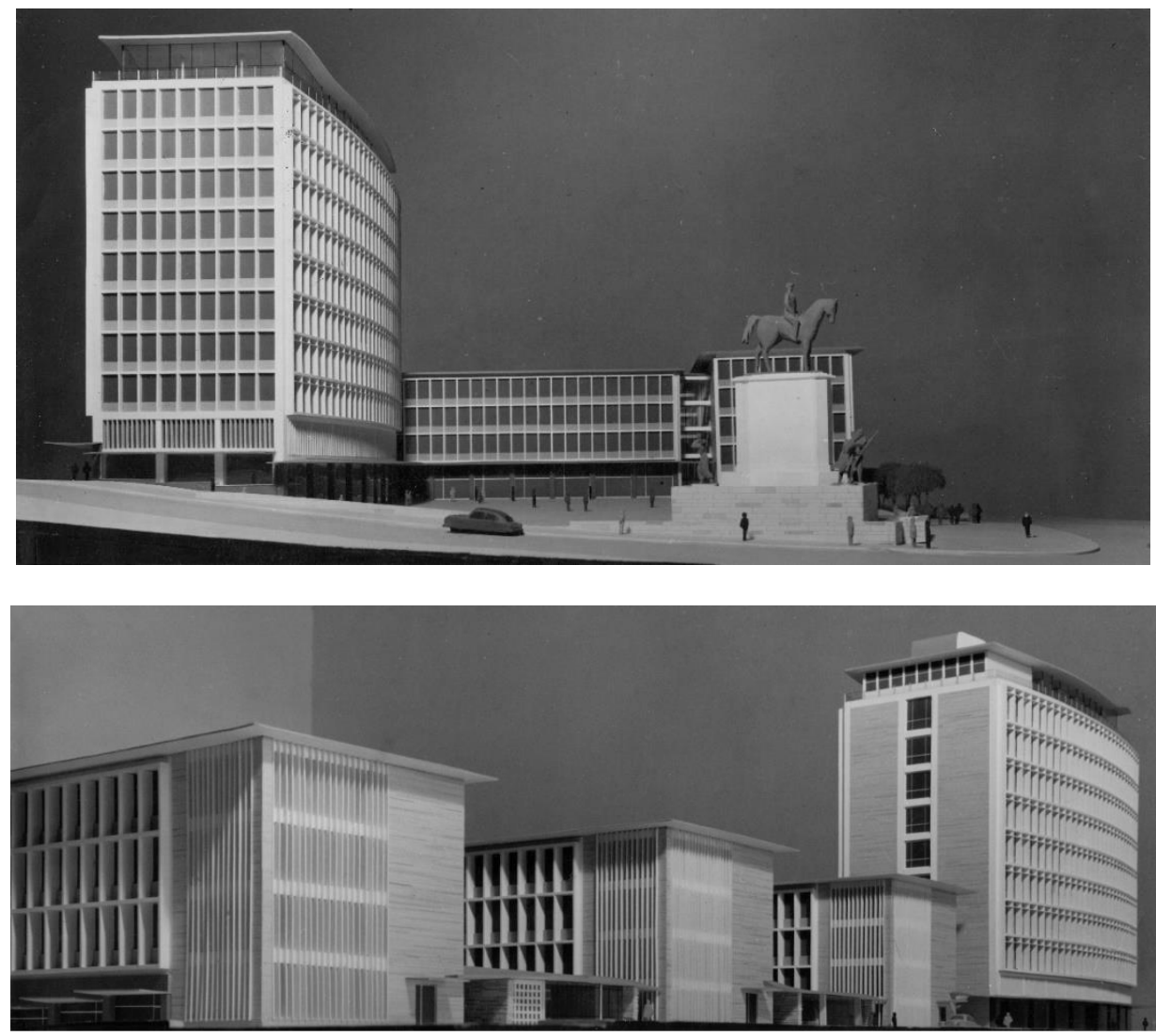

Figure 1 - Ulus Square Office Complex, Photo of Competition model, Courtesy of Arif Ergüleç (archivessaltresearch.org).

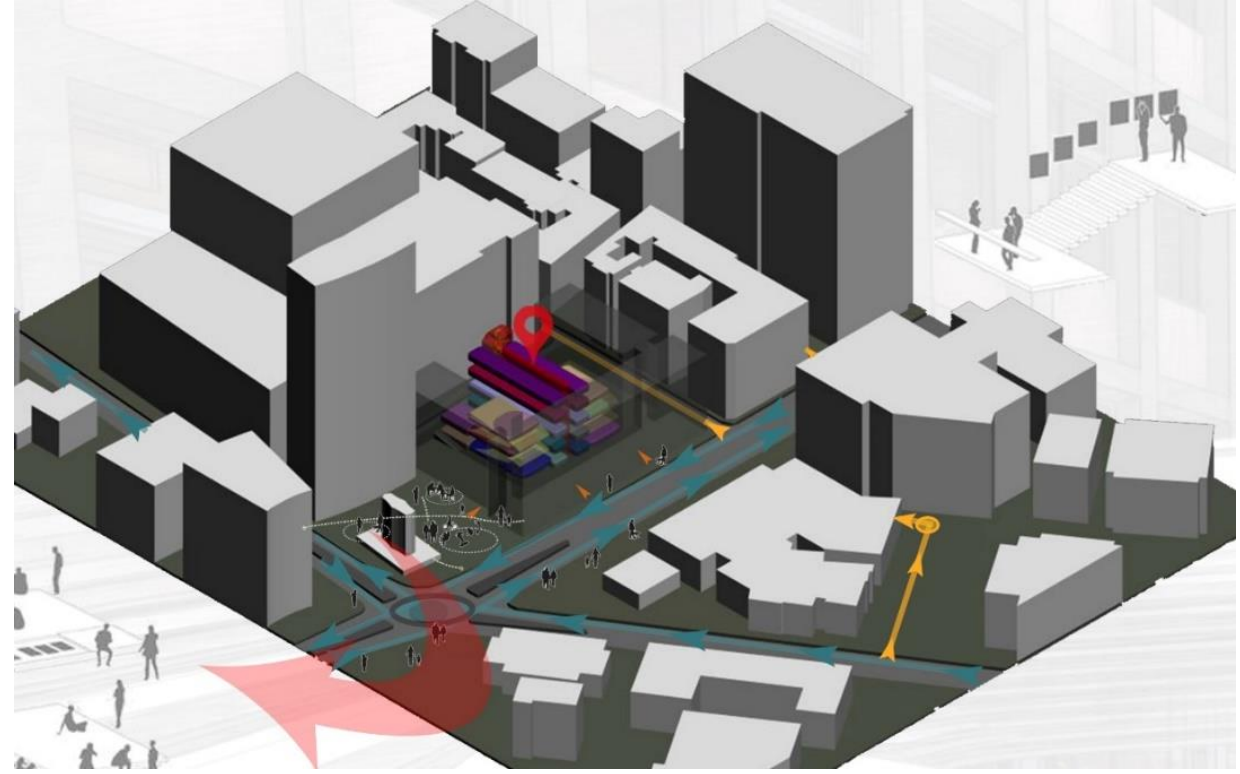

Figure 2 - Bilal Taşkın's site analysis 
In 1983, Ulus and the Historical City-Center were incorporated into the conservation areas, accepted by the Law on the Protection of Cultural and Natural Assets \#2863. As municipalities possess the authority to develop conservation development plans, Ankara Municipality opened a 1986 national competition for the urban planning and conservation of Ulus, the historical city center. The Conservation-Rehabilitation Plan of Raci Bademli and his colleagues won the competition (Tunçer, 2005). However, due to the inconvenience of urban texture and ownership status, the plan ceased to be implemented. Following the enactment of Law no. 5366, the "protection areas" identified by the 1986 conservation plan were declared as "renovation areas" with the decision no. 9289, dated 08.08.2005. The controversial story of Ulus Square and the Office Complex began with this decision. Following the commercial, touristic and cultural development of the region, the 2006 plans, prepared by the municipality, aimed to renovate or rebuild residential, commercial, recreation, and tourism areas, with new transportation solutions. In 2008, the court decided to suspend the execution of this plan. Since then, the Ulus Historical City Center remains unplanned (Asar, 2012, 38-42).

Ulus Square is a significant landmark for the historical city center as it houses the statue of Atatürk, Victory Monument (1927). Iss Bankası and Sümerbank buildings, Modern bazaars such as 100 Year Bazaar (100. Y I l Carşısı), Anafartalar Bazaar, and Ulus Square Office Complex surrounding the Ulus Square are significant cultural assets of Turkish architectural heritage. The Ulus Square Office Complex (Ulus Carşısı), composed of a high-rise office block and four-story business and shopping center with inner courtyards, creates this urban public zone. Its documental value for modern architectural history emanates from its Modern identity, which deserves conservation on the first level. As the historical city center ceased to be protected by a conservation plan, the former conservative municipality developed an urban transformation project for renovating the historical city center. The transformation project proposed the demolition of Anafartalar Bazaar and the high-rise block of Ulus Square Office Complex while preserving low-rise blocks around the courtyards to be re-functioned as a city hotel. This partial renovation/partial destruction project drew heavy criticism on both political and professional levels due to its being an attack on Modern identity and the Republican soul of the historical center. Moreover, the re-functioning of the lowrise blocks into a hotel would annihilate the publicness of the square as it would limit the entrance of the city residents into its courtyards, which held a notable place in social life and the collective memory of the Ankara citizens (Akdoğan, 2018, 383-415).

Ulus Square Office Block and Anafartalar Bazaar, both award-winning competition designs, retain cultural and architectural values for the recent past and collective memory of Ankara city. Designed by Orhan Bozkurt, Orhan Bolak, and Gazanfer Beken, the Ulus Square office complex (1954) has a modern and universal style, innovative for the 1950s and contrasted with Sümerbank and First National Assembly Buildings' nationalistic style. While limiting the publicness of Ulus Square, the complex infiltrates public access into its courtyards via the shopping function. This dual character of boundaries limiting public access proves its value as an urban structure and a cultural asset. Designed by Ferzan Baydar, Affan Kırımlı, Tayfur Şahbaz for low to middle-income individuals, Anafartalar Bazaar (1967) and its cubic structure, the curtain-wall materials, and new technologies used, documents the supremacy of pure Mies Vander Rohe-like attitude among the Turkish architects of the 1960s. As the first cornerstone of the shopping center trend in Ankara today, 
Anafartalar Bazaar is an architectural legacy that guards several ceramic artworks of the 1960s contemporary Turkish ceramic artists (mimarlaodasiankara.org). Its demolition, therefore, means the obliteration of esteemed public art.

The ceramic panel works of Füreya Koral, Seniye Fenmen, Cevdet Altuğ and Atilla Galatal, and the murals made by Arif Kaptan, Nuri İyem and Adnan Turani, are still mounted on the walls of Anafartalar Bazaar. All are exemplary works of contemporary Turkish ceramic art, mostly ranging from abstract to surrealism (Ertemli, 2006, p.41; Akdoğan pp.406-407). For example, the enormous surface study, exhibited on the entire wall surface of the escalator hall, was designed by Cevdet Altuğ in 1963. (Fig.3) Altuğ abstracted an astronomical theme by connecting nine circular panels (H. 25.91 X W $12.1 \mathrm{~m}$ ) with flat strips in this immense composition. While the circular panels in various colors, covered with rectangular geometric tiles, imitate the form of planets in the galaxy system, the hemisphere spots, sculpted on panel surfaces, imitate the craters with relief effects. Another glazed ceramic panel (H.354 X W.555 cm), found at the east entrance, was designed by Füreya Koral, the first ceramics artist in Turkey (1910-1977). (Fig.4) Koral, a connoisseur of contemporary ceramics art, received international recognition due to her synthesis of eastern and western motives with local touches (Sevim, Yeşilmen, 2017, 127). The work is an abstract and colorist open composition, focusing on the emotional conflict between the high-relief amorphous forms in brick red, placed in the middle of the design to the left, and the dark-colored helical forms and linear textures placed on the right. Two other rectangular ceramic wall panels installed on the first floor also belong to Füreya Koral. The first is a dynamic composition (H. 257 X W. $103 \mathrm{~cm}$ ) depicting an S-form created by the linear wave-shaped textures in cyan and orange colors against the cobalt-blue background. (Fig.5) The second work is an open composition portraying abstract bird patterns with white-glazed texture effects that Koral etched on the turquoise rectangular panel (H. 270 X W. $97 \mathrm{~cm}$ ) (Fig.6). The ceramic panel on the 3rd floor is another abstract colorist composition of Koral in rectangular form, composed of rectangular tiles with a matt black opaque glaze. The cloud-shaped figure at the top of the panel highlighted in orange color is excavated and cut arbitrarily and is filled with blue-colored melted glass (Fig.7). The two-piece ceramic work (H. 332 X W. $597 \mathrm{~cm}$ ) by Atilla Galatal1 (1936-1994) welcomes visitors at the west entrance of the bazaar (Fig.8-9-10). In the abstract and colorist work of Galatal1, the elevated and recessed circular geometries in various sizes create a depth effect with the bas-relief technique. These textures, formed by shaping the clay, and the colors, tinted by melting the glass on the glazed surface, emphasize the dynamic character of the panel by light and shadow plays. The panel works of Seniye Fenmen (1918-1997), inspired by her painting education, achieves their plastic value through textures shaped by Peinture and mosaic applications. Her first ceramic panel (H. 236 X W. $80 \mathrm{~cm})$, located on the third floor, colored in dark green and gray tones with transparent glaze and copper oxide, draws attention due to its chaotic mesh (Fig.11). Fenmen interpreted the joint gaps between tiles as linear artistic disjunctions and accentuated this effect by a dense texture caused by linear texture applications and their agglomerations on the glazed surface. Generally, her works articulate a naturalistic and mature color palette with the oxides. (Fig.12-13). (Can, 2018, pp. 85-107) The murals by Nuri İyem (1915-2005) on the first floor, Arif Kaptan (1918-1997) on the second floor, and Adnan Turani on the third floor are among other significant artworks. Mounted on the vertical bearing element in the middle of the third floor with dimensions of 340x146x632 cm, the mural of Nuri İyem is an abstract composition, which acquires a sculptural identity (Fig.14). 


\section{૬રરણ}

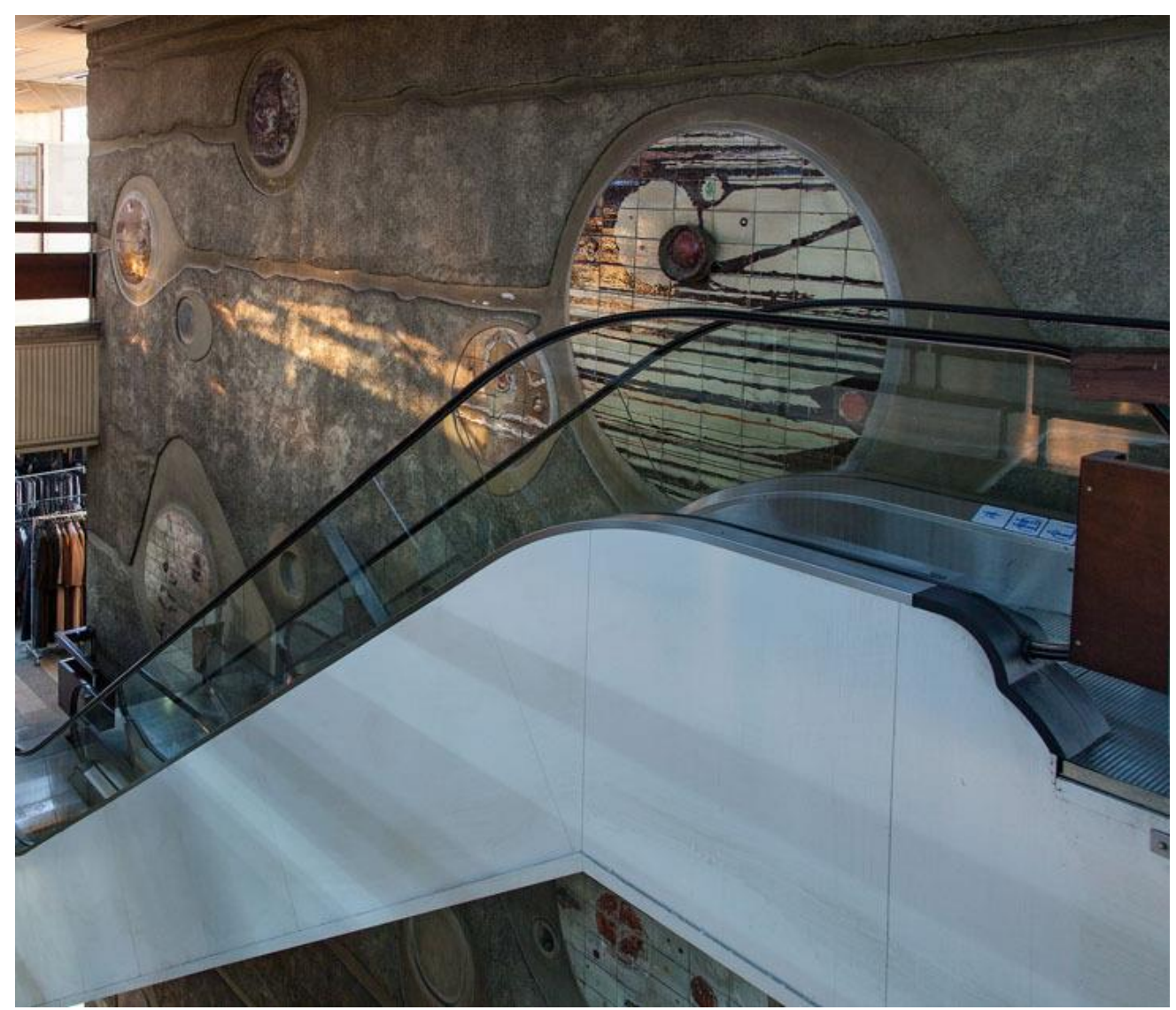

Figure 3 - Cevdet Altuğ (Can, 2018)

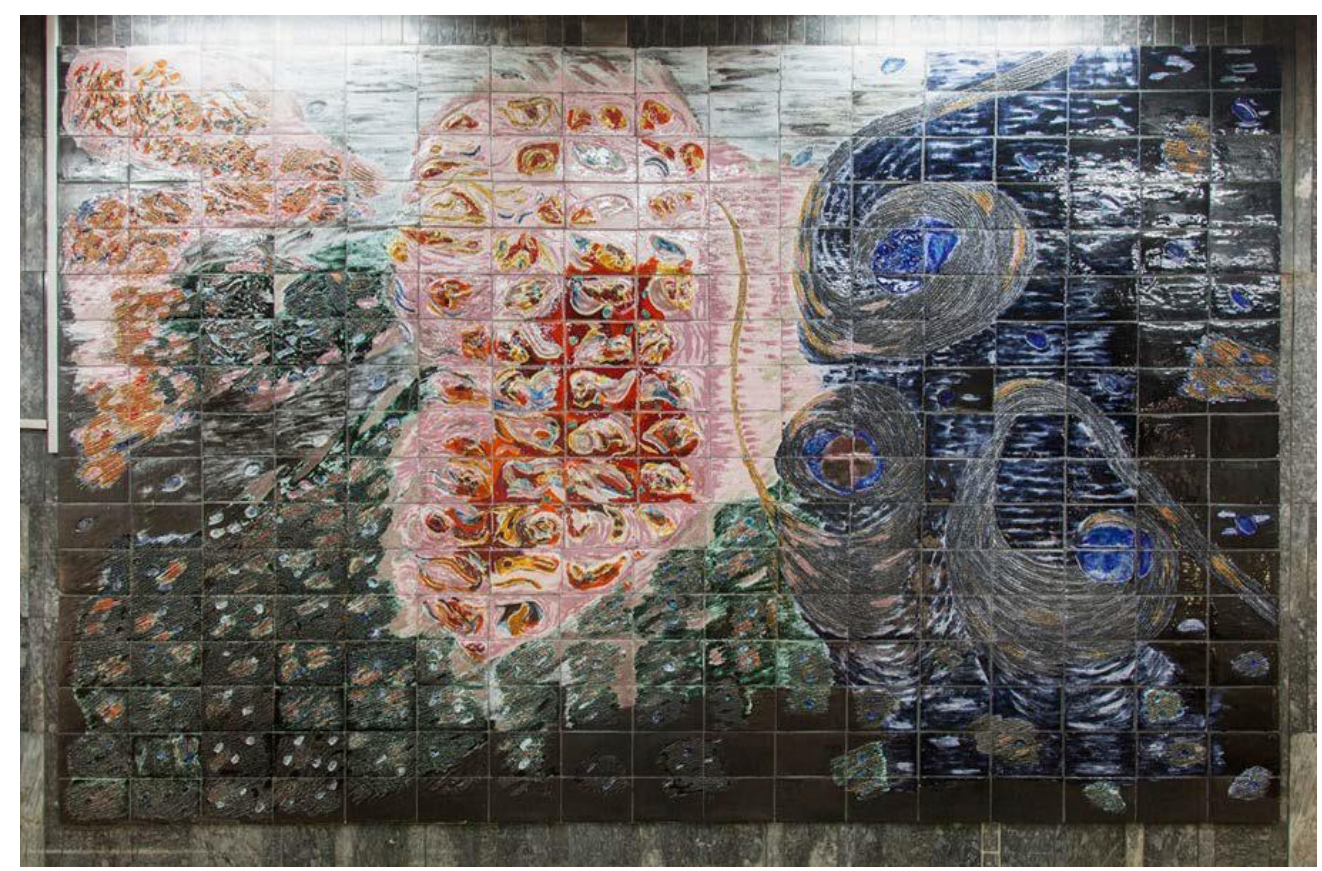

Figure 4 - Füreya Koral (Can, 2018) 


\section{Gરા]}

Vol. 4, No. 2, 202 I, I63-I92 / Cilt 4, Sayı 2, 202I, I63-I92 / DOI: 10.37246/grid.929577
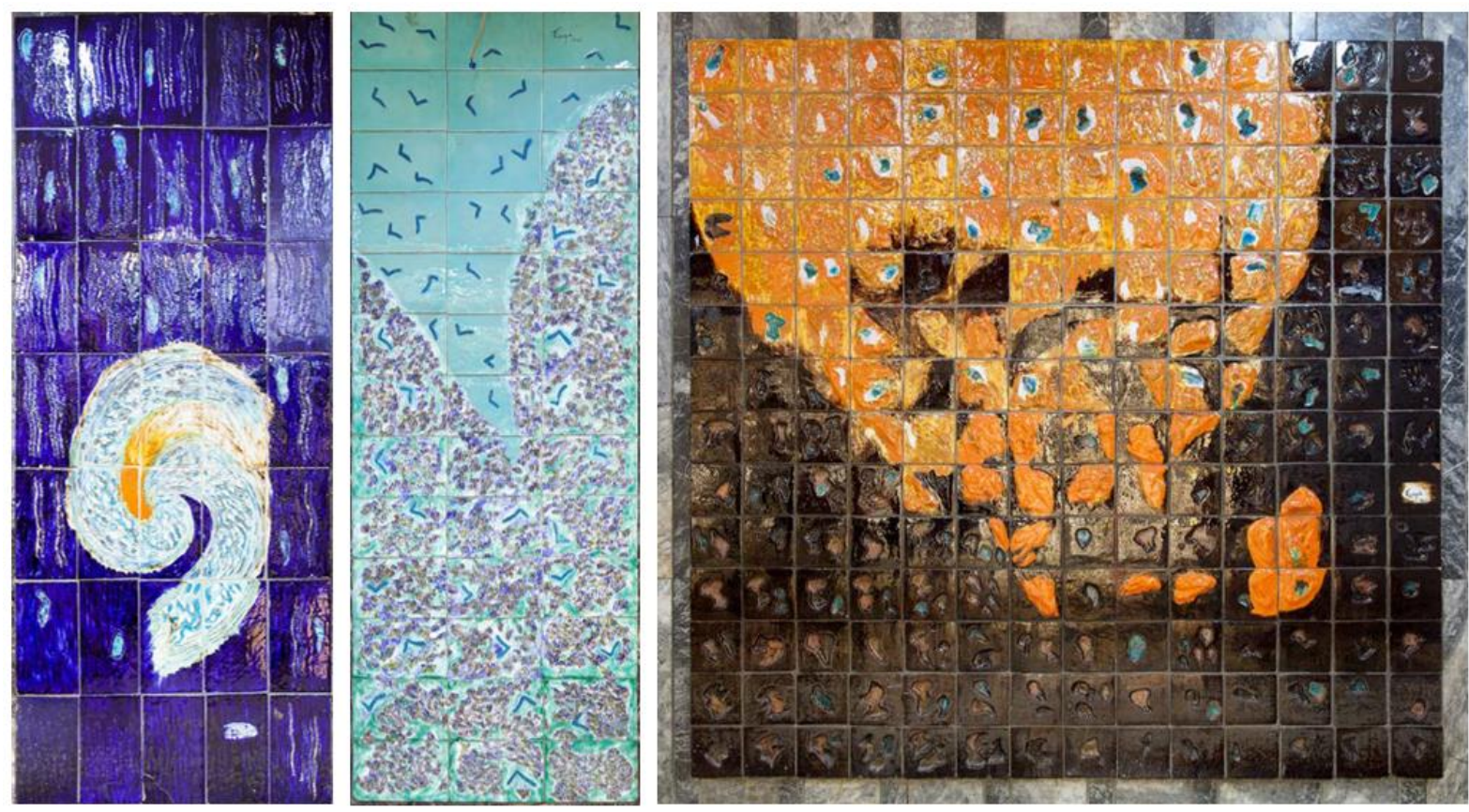

Figure 5- 6- 7. Füreya Koral 1963 (Can, 2018)
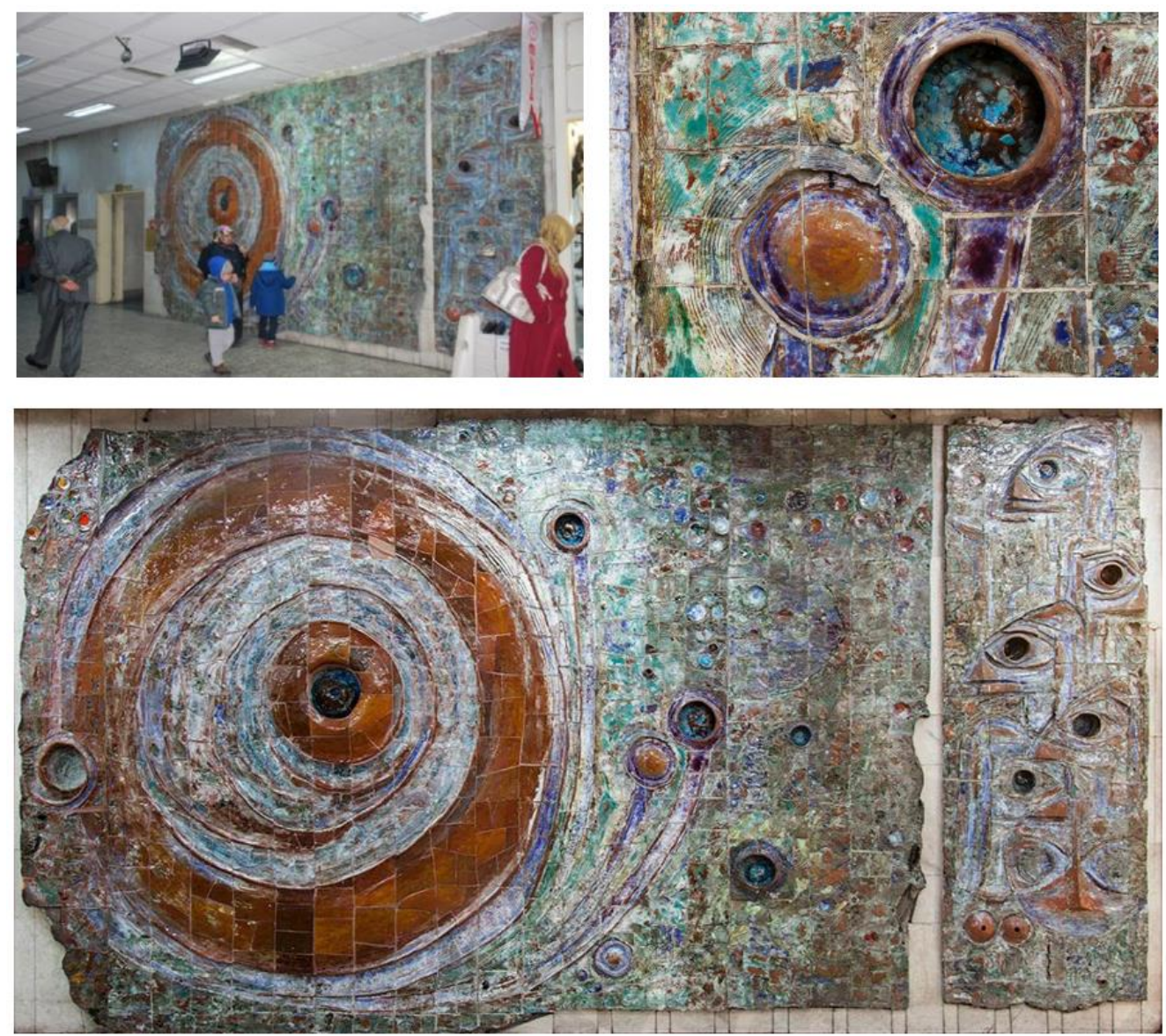

Figure 8-9-10. Atilla Galatalı 1963 (Can, 2018) 


\section{૬રણગ}

Vol. 4, No. 2, 202 I, I63-192 / Cilt 4, Sayı 2, 202 I, I63-192 / DOI: 10.37246/grid.929577
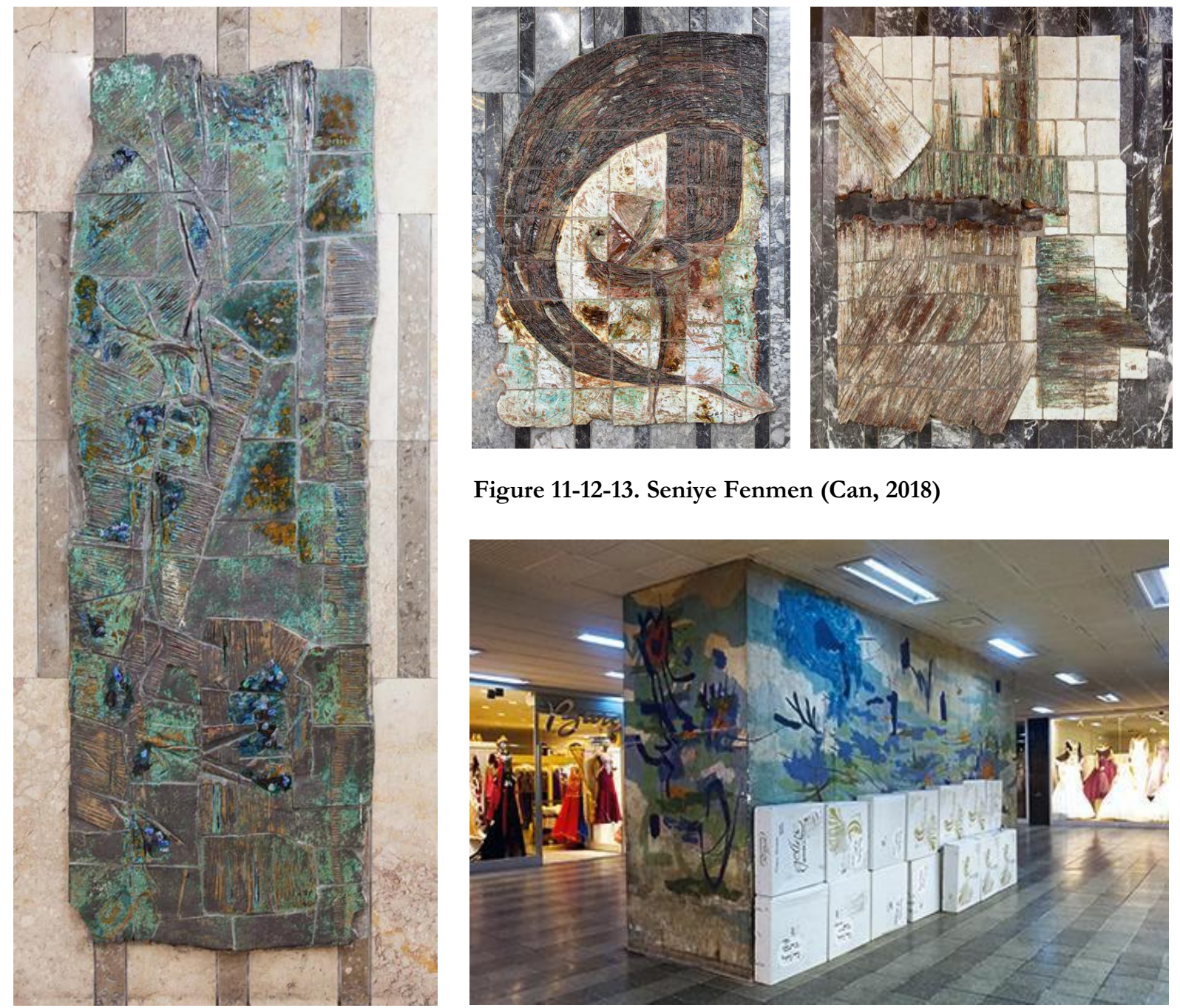

Figure 11-12-13. Seniye Fenmen (Can, 2018)

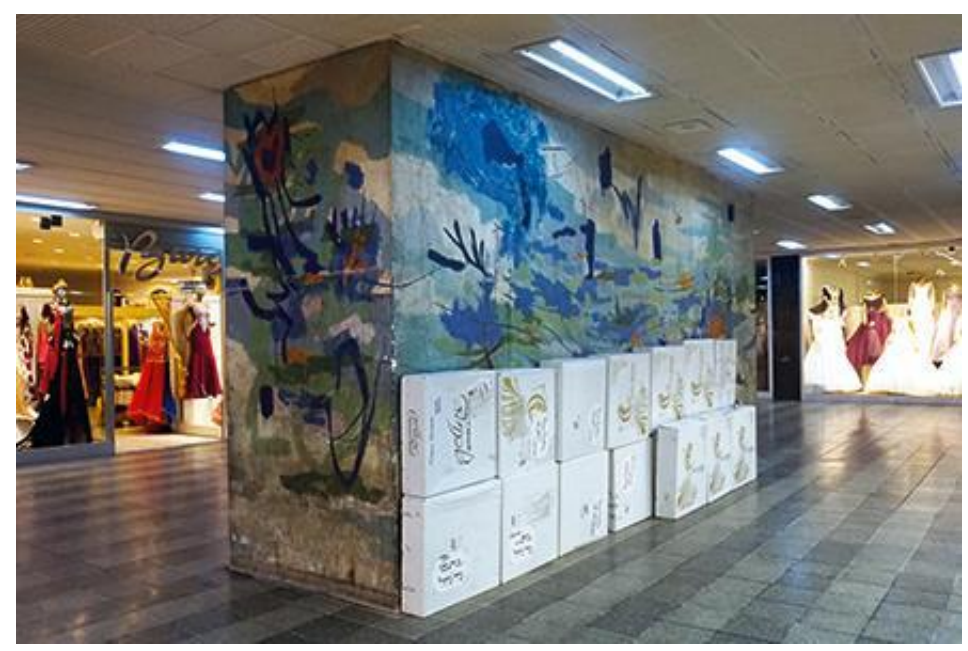

Figure 14. Nuri İyem (Can, 2018)

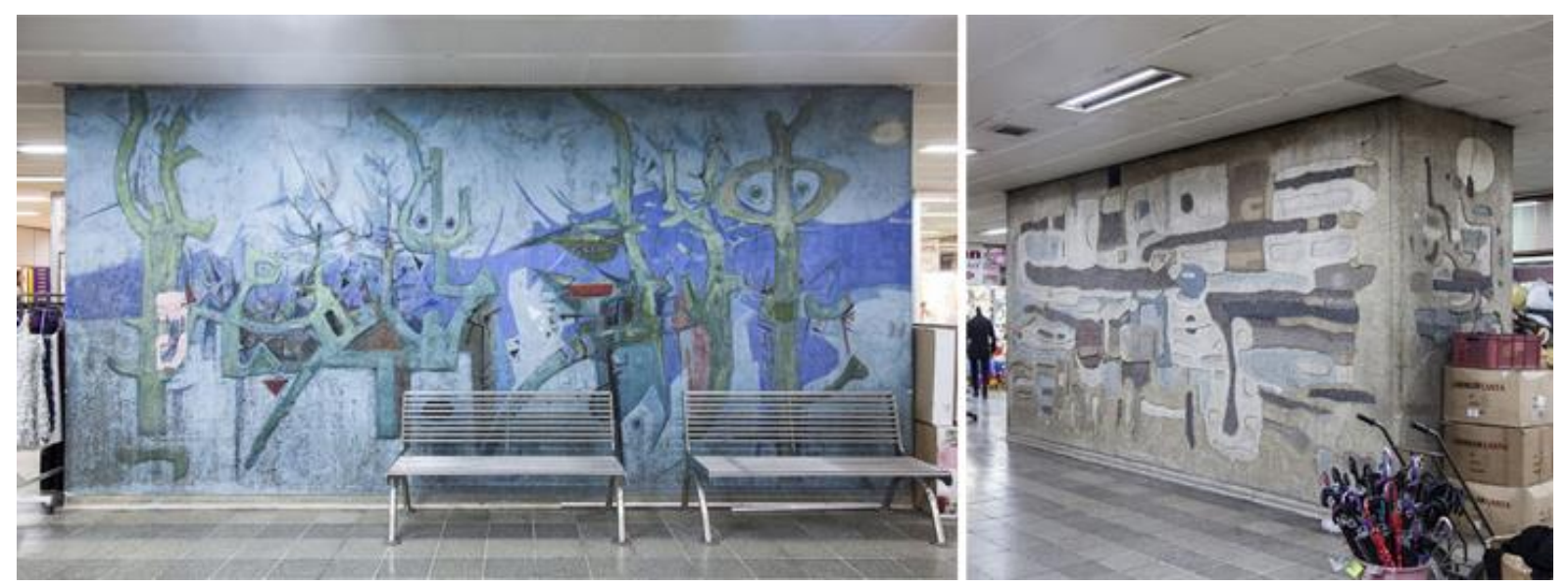

Figure 15-16. Arif Kaptan (on the left), Adnan Turani (on the right), photos by Can Mengilibörü (artikera.com) 
The abstract design of Arif Kaptan installed on the second floor attains a calligraphic impression due to the figure-ground relationship captured between the abstract figures on the colorless background (Ertemli, 2018, p. 54-60) (Fig. 15). The mural of Adnan Turani found on the third floor is abstract-geometric sgraffito, depicting embossed and juxtaposing rectangular geometries with apertures (Fig.16).

One can sense the relativistic relationship of architectural work and artworks it guards, through the words of Bedri Rahmi Eyüpoğlu, the renowned painter and ceramic artist, in a 1975 interview: "A ceramic art needs to get installed on the walls of architectural work for a living." For Eyüpoğlu, ceramics live longer and provide more publicity if guarded by an architectural entity. As claimed by Cengizkan, Eyüpoğlu identifies the architect/architecture as the custodian of the artist/ceramic art. What if the architectural structure cannot protect itself, consequently the ceramics it guards? That is the case in Anafartalar Bazaar. As also criticized by Cengizkan, the preservation problems of architectural heritage, regardless of their artistic, historical, and cultural significance, cease to protect both architecture and the ceramic art it guards. (Cengizkan, 2019, 234). Even the possibility of destruction of the ceramic panels and wall paintings in Anafartalar Bazaar prompted the artists/art theorists and academicians to publish numerous theses and articles criticizing the decision in the last decade. (Asar, 2012; Akdoğan, 2018; Büyükkaragöz \& Yayan, June 2019; Can, 2018; Ertemli, 2019; İpek, 2020; Kambak, 2019). All were comprehensive studies that provoked the awareness of intellectual lobbies on demolition decisions; however, two art installations by Kambak single out within the scope of Studio 302. Criticizing the obliteration of the Anafartalar Bazaar and its ceramics from the city memory that "eliminate the urban palimpsest" and provoke the society, Kambak uncovers the hidden codes of social memory embedded in the material with Sublimelma (2017). The video projection of forgotten silhouettes from public areas onto a metal structure, placed under the escalators of Anafartalar Bazaar, aims to provoke the users to go back and forth between demolition and construction beneath an up-and-down mechanism (Fig.17). With What a Demolition Builds (2018), a video-art, or as Kambak claims, "video- construction" of a "digital mosaic," Kambak digitally rebuilt the ceramic works in the bazaar by adhering to the building plan (Fig.18). The rhythmic appearance and disappearance of ceramic panels, being featured in each shot, symbolized the erasure of the bazaar from collective memory (Kambak, 2019, 40-44).

The debate amongst artists and academicians regarding the demolition of Anafartalar Bazaar triggered concerns on the consequences of re-functioning a historical or cultural heritage with parametric means. Studio 302 searches for the answers to the following query: What will the refunctioning of Ulus Square Office Complex build? Can the students reclassify all decisions regarding artistic/cultural/historical values of Anafartalar Bazaar and office complex as unique parameters/rules/methods of a rhizomatic form-finding experience? Could the messages given by the artists of ceramics and murals in the bazaar inspire the students in developing a design strategy? How could all ceramic works be incorporated into the design process? Is it possible to combine mold and craft in design, at a point when design technique and technology are converging? (Spuybroek, 2016, 36). 


\section{Gર1D}
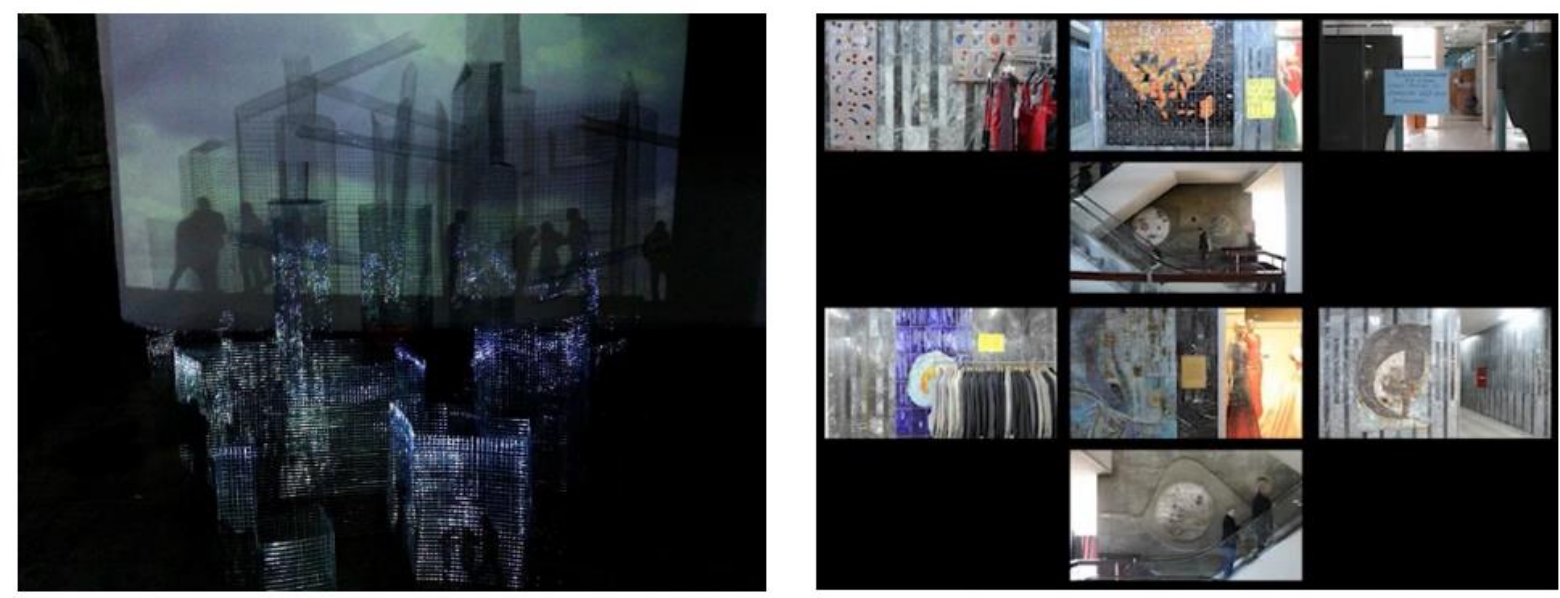

Figure 17-18. Sublimation, 2017, Video Installation, Wire and Projector, (1 min.10 sec.), What Does a Demolition Build?, 2018, Video, Projection (Kambak, 2019)

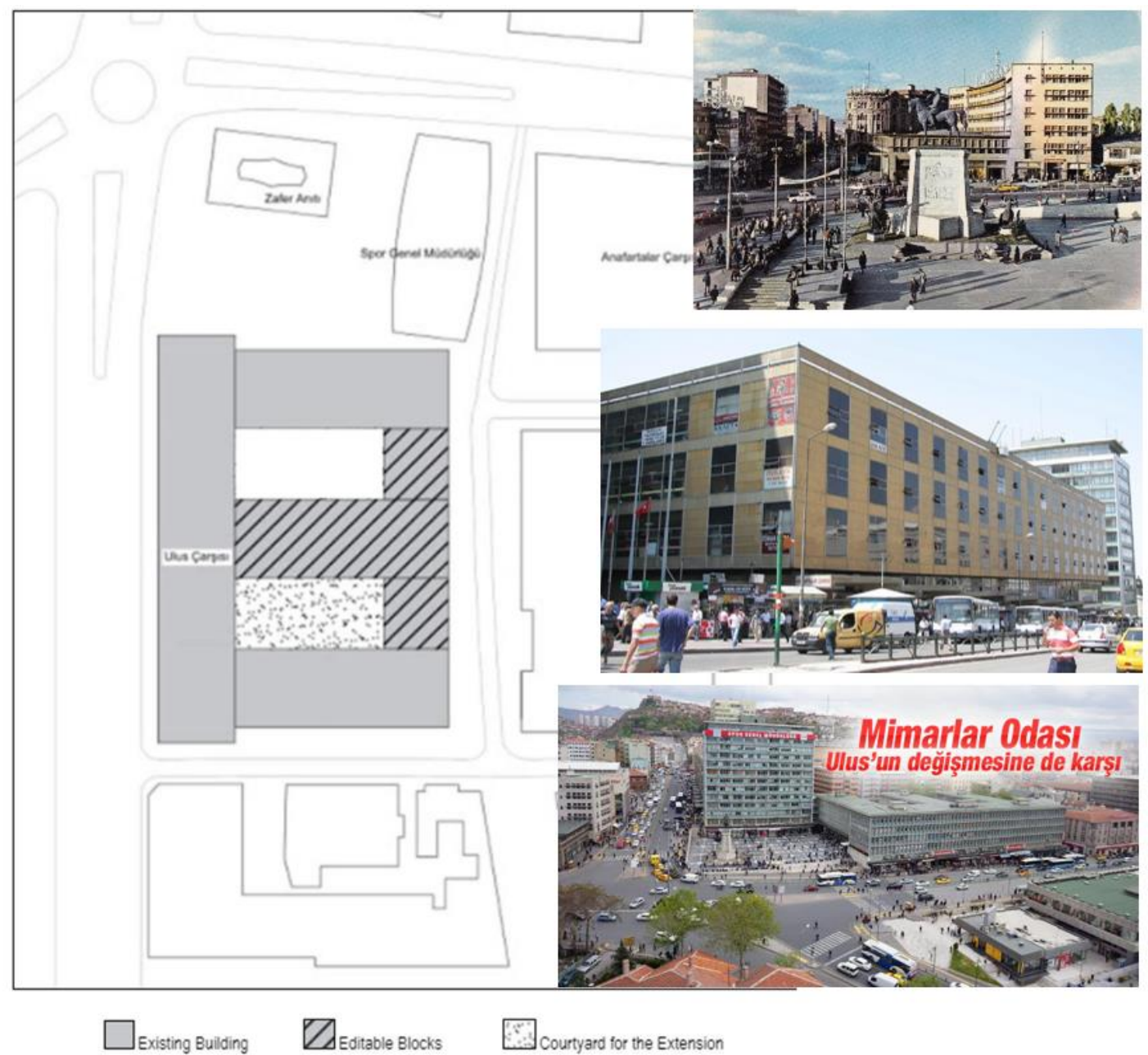

Figure 19. Project site (on the left), Ulus Square and Sümerbank, (right top), Anafartalar Bazaar (right center), Ulus Square Office Complex (right bottom) 


\section{THE PROJECT PROCESS: WHAT A DEMOLITION BUILDS?}

Considered one of the icons of modern architecture, Ulus Square Office Complex was an actor in the controversial story of demolition for ideological purposes (mimarlarodasiankara.org) The debates and polemics on its destruction, eliminating cultural and historical values, and the topic of the video construction of Kambak, What a Demolition Builds, inspired the fictional scenario of the Studio 302 design project. The complex has an E- type plan layout, composed of a central axis located parallel to the main boulevard and three interconnected wings divided by inner courtyards. The students were asked to re-function the middle block and the flanking wings on both sides as a boutique hotel with a futuristic extension at the left courtyard of the complex requiring $6100 \mathrm{sqm}$ in total, with at least fifty rooms and social spaces for exhibition, recreation, entertainment functions, and service areas (Fig.19). As the outer wings delimited the project site, the futuristic silhouette of the parametric form was camouflaged from the main boulevard yet offered an oasis as soon as one entered the courtyards.

Students analyzed Ulus Square Office Complex and its close periphery in the first stage. They developed creative maps from juxtaposed environmental/climatic analyses, sun/wind diagrams, and urban behavioral patterns regarding urbanite habits. Next, they explored the historical city center according to the five elements of the city, defined by Kevin Lynch in his seminal book on The Image of the City (1960): the landmarks, walking paths of users, the connecting nodes, the edges/boundaries, and zones/districts. Moreover, they selected one of the ceramic panels in Anafartalar Bazaar as the leading source of inspiration for their form-finding process, analyzed its form generation, and the complex relationships, listed by Lars Spuybroek (2011) as "mergings, braidings, splittings, crossings, branchings, overlappings" in the ceramic artworks. They tried to reproduce the inherent geometrical pattern through parametric means and interpret them as ornaments acting like structures. They also designed three-dimensional mass diagrams for their proposals that rendered the space allocation and zoning decisions, delineating the entrance/exits, public/private areas, and horizontal/vertical circulation. The initial form-finding exercises of the parametric rhizomes essentially benefited from the complex web of these environmental and behavioral analyses on the historical center and geometric/color examination of the artwork since the color is an integral part of interior design education. (See, Ural, Akbay, Altay, 2017). Considering cross-connections with mass diagrams, functional requirements, and fire safety regulations, the students developed creative concepts on the interior space configuration that determined the form-progress of parametric rhizomes, which metamorphosed into the architectural form of the futuristic extension. This stage ends with a pre-jury, evaluating student submissions, including site analyses, location plans and project briefs, architectural programs, mass diagrams, conceptual processes and form progresses, models, and color designs.

In stage 2 , the students started to work on the two-dimensional plans and sections of their projects in $1 / 500$ and $1 / 100$ scales. Focusing on the interior design of hotel spaces in sequence, they represented real-time video renderings of each zone using Lumion or Twinmotion software. Simultaneous processing of two-dimensional plan layouts and three-dimensional real-time video renderings facilitated students to overcome the complexity experienced during the transition of $2 \mathrm{D}$ expressions into 3D virtual environments. Specific concentration on color and mood boards 
prompted the advancement of the interior atmosphere quality. Sustainability, material and lighting preferences, the determination of wayfinding and sign systems in hotels were among the main topics of the 2nd phase. Student works in this stage were evaluated with a pre-jury, requiring PowerPoint presentations defining their conceptual development and form progress, twodimensional representations of the site plan in 1/500 scale, floor plans (furnished), reflected ceiling plans, and sections in 1/50 scale. Besides, they presented three-dimensional video renderings of their proposal, following a movement path starting from the entrance towards the public and room functions. They provided brief information about the specification of materials preferred for wall/ceiling/floor; adopted the color design specialized according to the functional demands in the video presentation.

In stage 3, students continued to revise all phases of the project according to instructor critiques. They often concentrated on the construction details of the selected areas. They implemented the fire safety design in light of regulations and laws, schematized HVAC system proposals, and developed solutions for energy efficiency. Moreover, they concentrated on the system details of deluxe and suite rooms on the $1 / 20$ scale, where they metamorphosed their rhizome conceptions into bedroom furnishings, namely ceiling to floor patterns, built-in and mobile furniture designs. At this stage, students mainly worked on construction details. Student works at this stage were evaluated with a pre-jury requiring the revisions of stages 1 and 2 , including $1 / 20$ scale orthographic drawings with all joint detail solutions, color and material boards for deluxe and suite rooms, and three-dimensional video renderings using Lumion or Twin Motion software.

Overall, this has been a challenging design project that, we believe, helped evolve the design thinking process of the students. By integrating computer-aided design tools, they transformed conceptual ideas derived from ceramic artworks and environmental analyses of the historic site into the parameters of futuristic architectural form and diverse rhizome interpretations due to functional changes in the interior space. Designing parametric rhizomes in architectural space, employed as a teaching strategy, can be justified by analyzing student approaches towards the problem. The following queries might shed light on its applicability:

- Has emulation of an artwork as a source of inspiration, in this case, ceramic artworks, become a practical basis for form-finding experiments?

- Has coherence to the environmental factors and the architectural fabric been deterministic in the form generation of the parametric rhizomes?

- Has rhizomatic conceptualization and transformation expectancy compelled the students to capture a solid design language?

- Has the interpretation/utilization of rhizomes as a design/teaching strategy become a heuristic approach for Interior Architecture students/tutors in the apprehension/clarification of the parametric form and complex function relationship? 


\section{PROJECT EXAMPLES: METHOD / PARAMETRIC FORM / INTERPRETATION}

Student interpretations of the artwork into the rhizomatic structure differed from each other, as they came up with design solutions in their unique way. As seen in the following project examples, the students did not limit themselves to the ceramic layout but rather amalgamated them with the historical and environmental values of the site as defined above. Some students deciphered the concept of rhizome as a form-finding strategy; some interpreted it as a plan syntax solely as if refusing to acknowledge its metamorphosis. The following student projects also demonstrate various interpretations of the same artwork by different students.

For instance, Bilal Taşkın reinterpreted the bird nest-like space left between the brown-toned circular form and the sword-shaped triangular spot in the ceramic panel of Seniye Fenmen as a form-finding method. The figure/ground contradiction between brown figures and the white background created an oasis with abstract narratives. This oasis inspired the rhizomatic formfinding approach of Taşkın that he interpreted as voids within the continuous linear planes with the application of the grid spreading method in the Grasshopper software. These voids hosted public functions, such as the cafe, lobby, and circulation paths. For establishing a solid design language, Taşkin employed the formal approach of the ceramics in the plan layout as circular spaces. Hence, in the context of the interior space, the circular utilization of the plan was accentuated by the use of multiple horizontal lines, creating a multi-layered atmosphere by the use of linear finishings, such as ceiling, lighting, wall, and floor treatment. The strategic mutation of rhizome, redefined by Taşkın on multiple tiers, demonstrated his competence in apprehending the metamorphosis of parametric form in diverse circumstances and screened his deliberate ignorance in cohering with environmental factors and the architectural values of the project site. (Fig. 20)

Esma İlhan, on the other hand, reinterpreted the elevated and recessed circular geometries of Atilla Galatalı in various sizes to create a relief effect as her form-finding method. Designing craters that sometimes ascend and sometimes descend in the architectural shell, Illhan acquired a sense of depth in the facade. The existing building and the extension enclosed with linear brise-soleils, carved by the circular facade openings, imitated the relief-like textures of Galatalı on a striped surface. The relief effect, depicted on the architectural shell, was also duplicated on the plan layout and materialized the spatial boundaries of public functions as amorphous eggs. The geometric order, emulated from the ceramics and captured on the facades of the architectural shell, has continued in the interior space setup, transforming into circular social spaces oscillating in the atrium. The rhizomes of İlhan, interpreted as the suspended eggs, began with the architectural shell and maintained their continuity within the interior space. Her continuous brise-soleils represented the axial and vertical effect created by the window moldings on the existing facade. The Cartesian column-beam system and contextual axial order began to disappear in the compresence of the parametric forms in her project, in the manner that the color and form application suppressed the contextual grid in the ceramics of Galatalı due to nature and application techniques of the material. As İlhan mostly limited her unilateral deployment of the rhizomes to the ceramic layout as spatial entities refusing to undergo any metamorphosis into interior furnishings, she preferred to demonstrate them to the exterior through the voids carving the facade. (Fig. 21) 


\section{૬રા]}
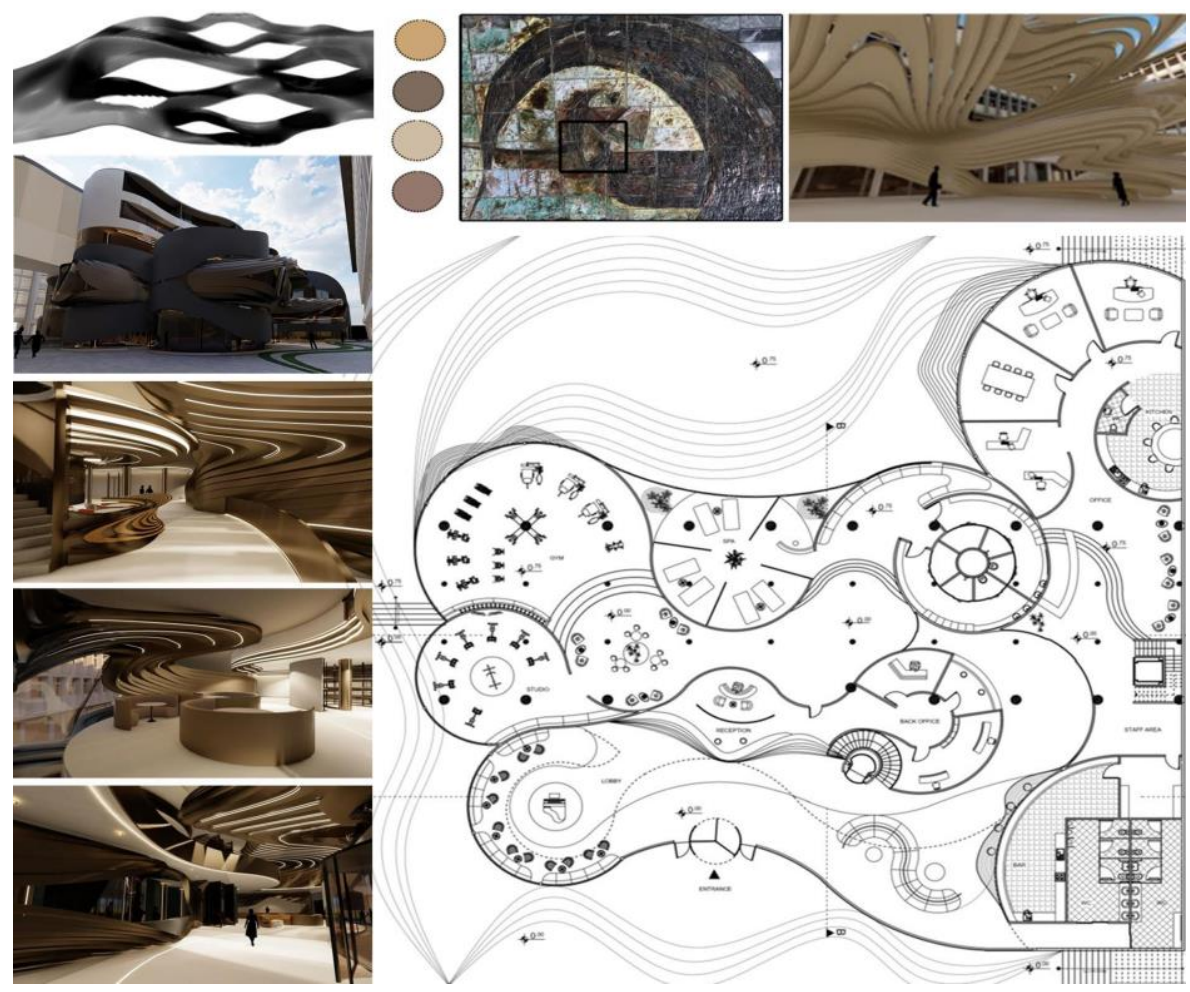

Figure 20. Bilal Taşkın
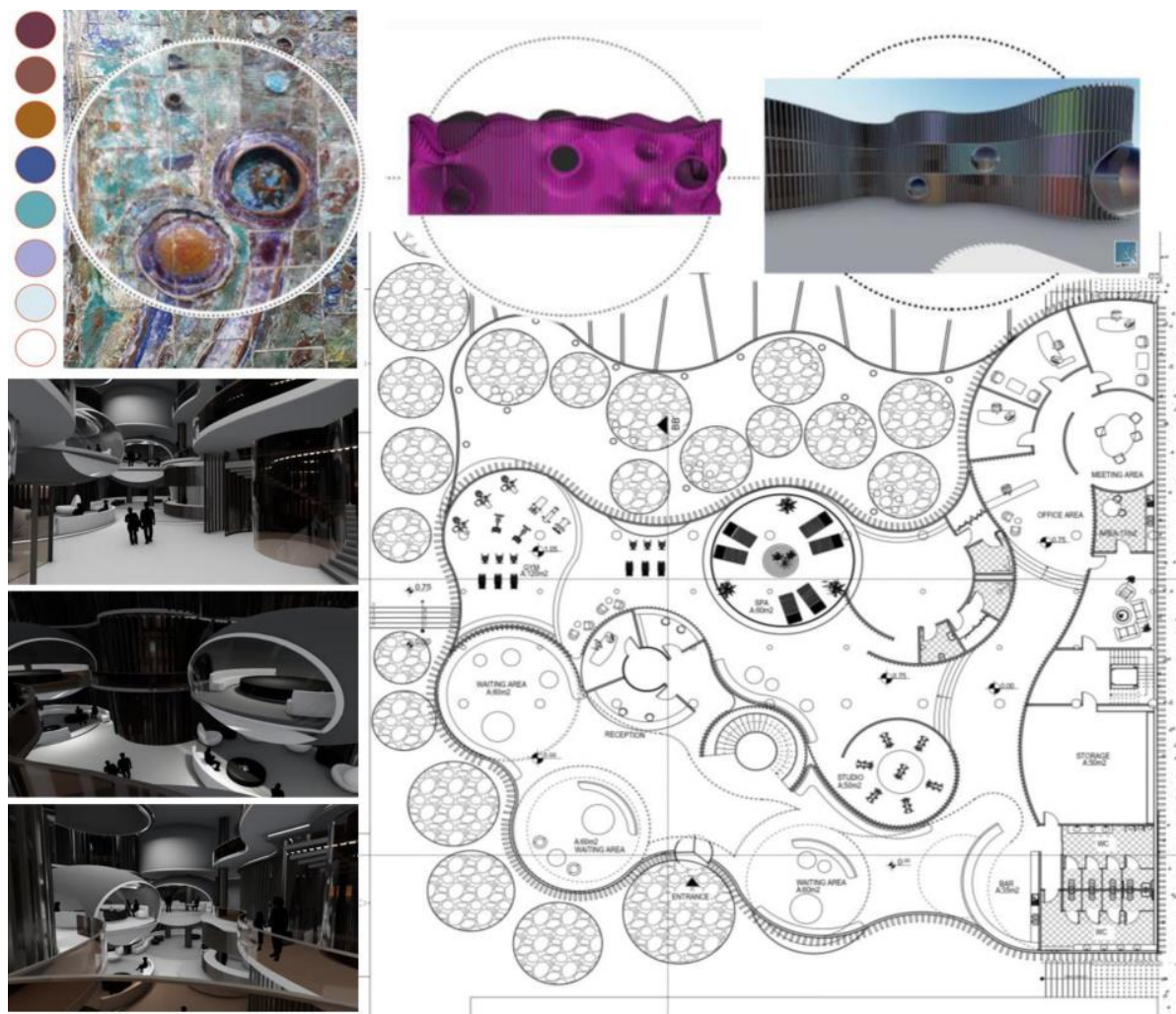

Figure 21. Esma İlhan 
Hüseyin Can Çelebi selected the same ceramic piece of Galatalı as the inspiration for his project. Accepting the depth creation of Galatalı by relief effects as a principle, he created a translucent parametric shell yet, in contrast to İlhan, rendered its relation with the existing building much more palpable. Çelebi reinterpreted the static alignment of vertical moldings on the existing facade as the structural order of the triangular extension. The geometrical contrast between the sequential order of the structure and the dynamic silhouette of the parametric shell represented a solid contextual relationship with both the historic environment and the ceramic work. In this specific project, both the ceramic artwork and the architectural values of the building inspired the formulation of the parametric form. In the interval between the orthogonal extension and the decorative shell, Çelebi replicated the courtyard experience of the existing building as rhizomatic interior foliage. However, he omitted to employ the circular depth effect grasped in the ceramics as the plan syntax of interior spatial organizations. The linearity versus organic nature transferred to the dual-rhizomatic adaptation in the project of Çelebi referred to both the axiality of the existing structure and the circular reliefs, denying the grid pattern of the ceramics. This contrast was also well balanced in the interior design; for instance, lighting fixtures of the lobby area with straight angles contrasted with the organic design approach embraced in the reception area. The parametric rhizome of Çelebi manifested itself as a decorative shell yet resisted to condition and correlate itself with the changing functional demands of the project. (Fig. 22)

Aybike Karakaş, on the other hand, focused on the second panel of this two-piece work, designed by Galatali. In this second panel, the undulant relief effect and conflicts of depth, depicted in the first panel, were recaptured with eye forms. Karakaş valued the importance of proposing innovative solutions regarding the interior space. Conforming to the orthogonal design of the existing building, she interpreted the architectural shell as a solid block, which preserved the abstract geometrical order by layers of linear timber elements. Karakaş recreated the play of light and shadow in the ceramics of Galatalı by the filtration of natural light through the interstices between linear timber elements. The rhizome of Karakaş took the shape of a worm, carving a path in the semi-closed box, and created parametric voids that allowed the flow of one interior space to another. This worm-like path sometimes penetrated the building facade and vestibuled the solid block to carry the depth effect of reliefs in the ceramics. As the worm path protruded from and retracted to the hotel spaces sequentially, Karakaş acquired the unison of the existing structure and the parametric extension in the courtyard through the voids functionalized as social areas and circulation paths. The continual circulation of the parametric form, excavating voids throughout the functions, transformed it into a dynamic space generator. (Fig. 23)

The rhizomatic form-finding experience of Barkın Güngördü was inspired by the ceramic panels of Cevdet Altuğ, depicting a solar planet order. He segmented the architectural program into zones and created each zone as distinct planets in solid and transparent spherical shells. Differentiated in nature according to the functions they shelter, these spheres were bridged to each other with helical ramps, referencing the circular figures in the abstract configuration of Altuğ. Güngördü rendered the circular plan syntax, consciously neglecting the orthogonal structure of the existing building, so dominantly for representing the circular planets of Altuğ with his spherical rhizomes and depicted a seamless journey between them by his helix circulation. 


\section{૬રા]}
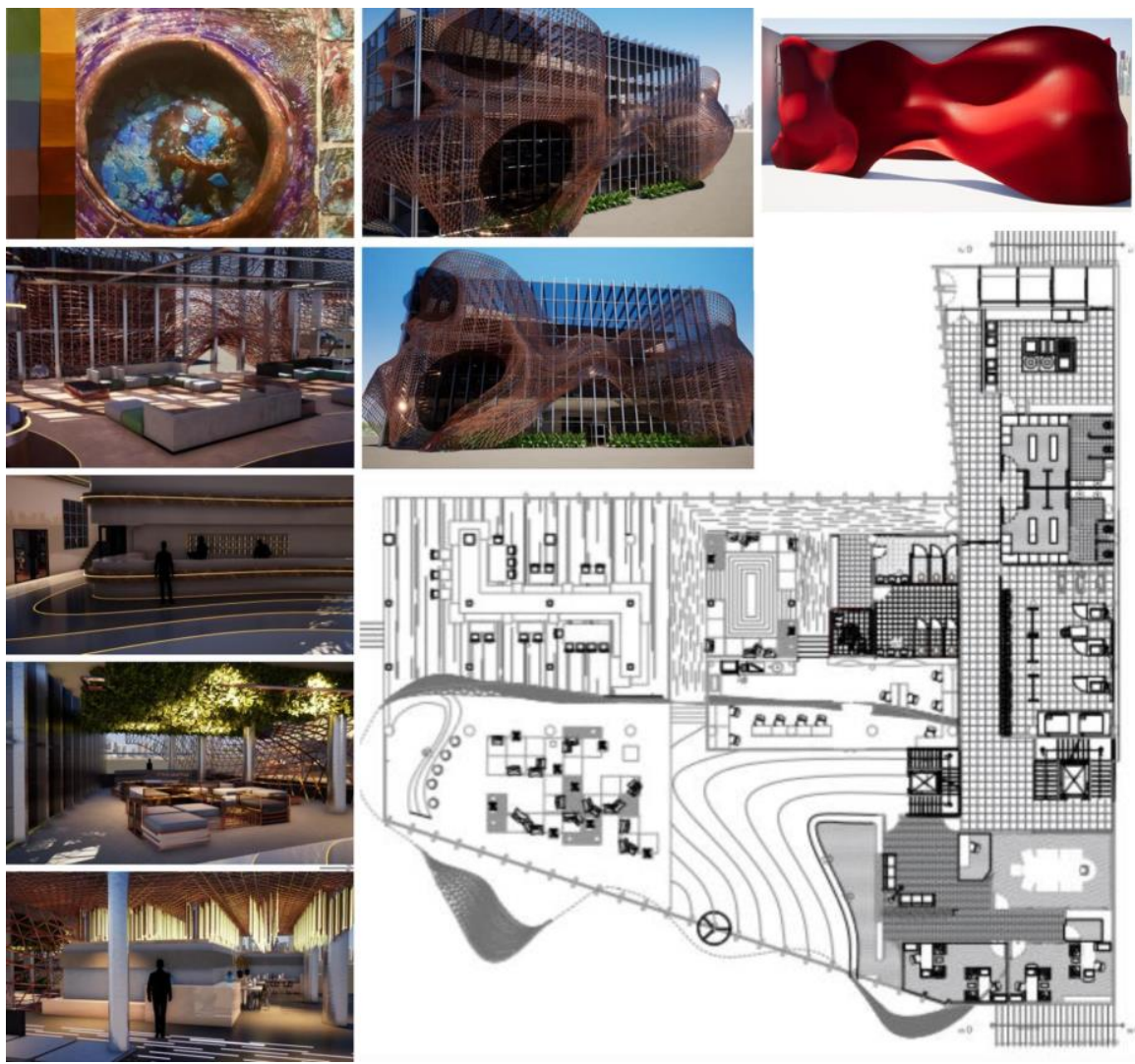

Figure 22. Hüseyin Can Çelebi
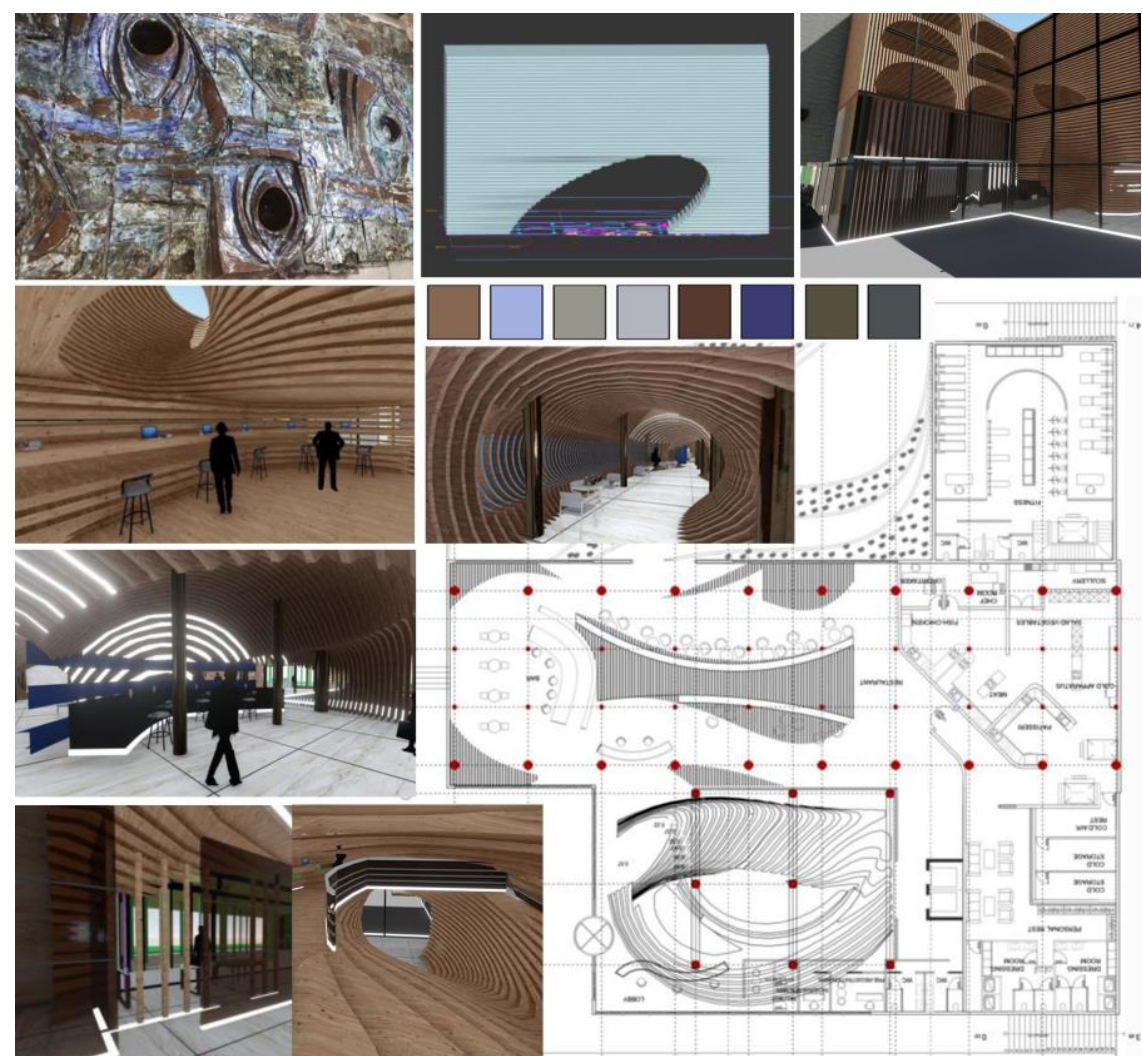

Figure 23. Aybike Karakaş 


\section{૬રશગ}

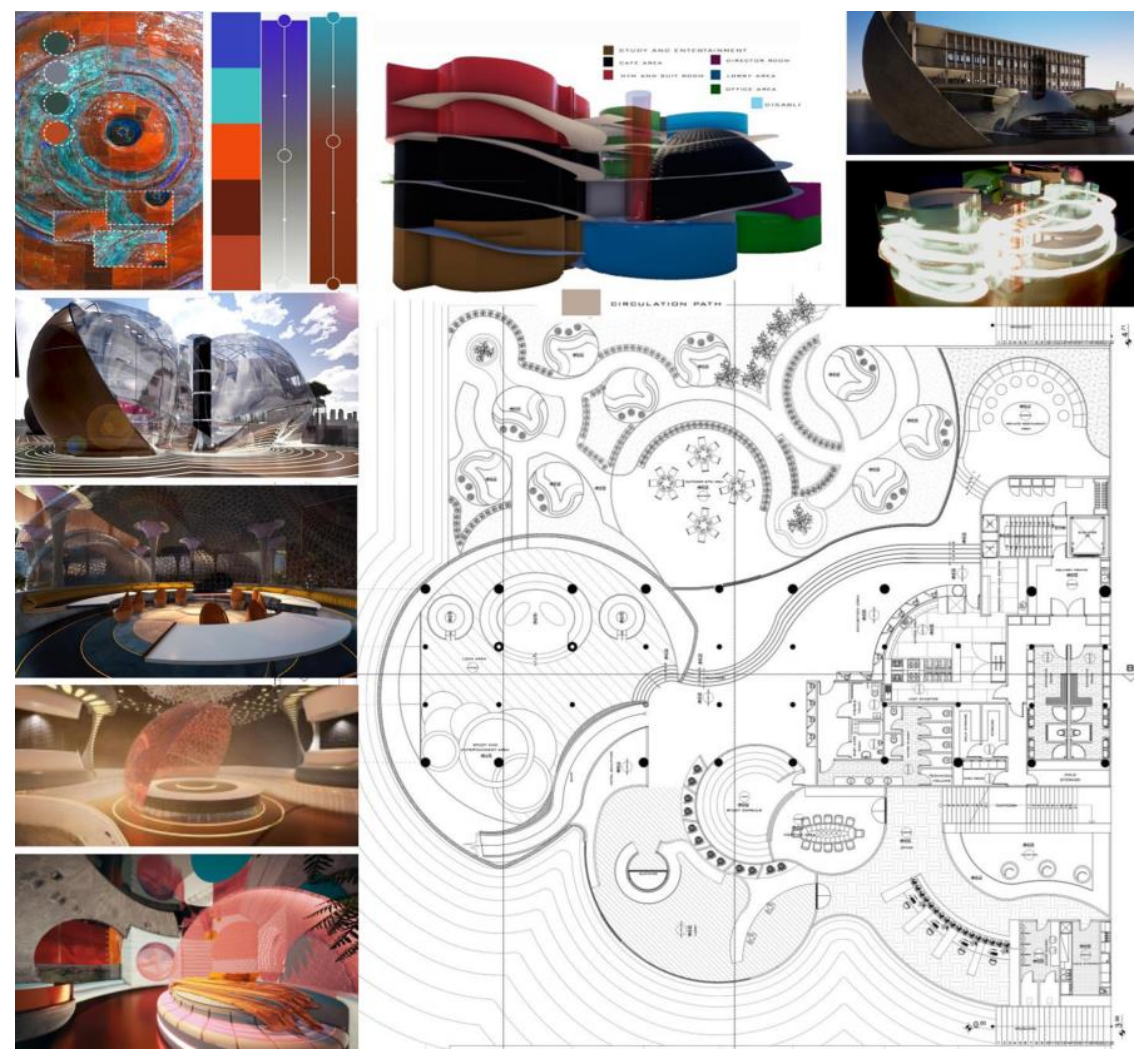

Figure 24. Barkın Güngördü

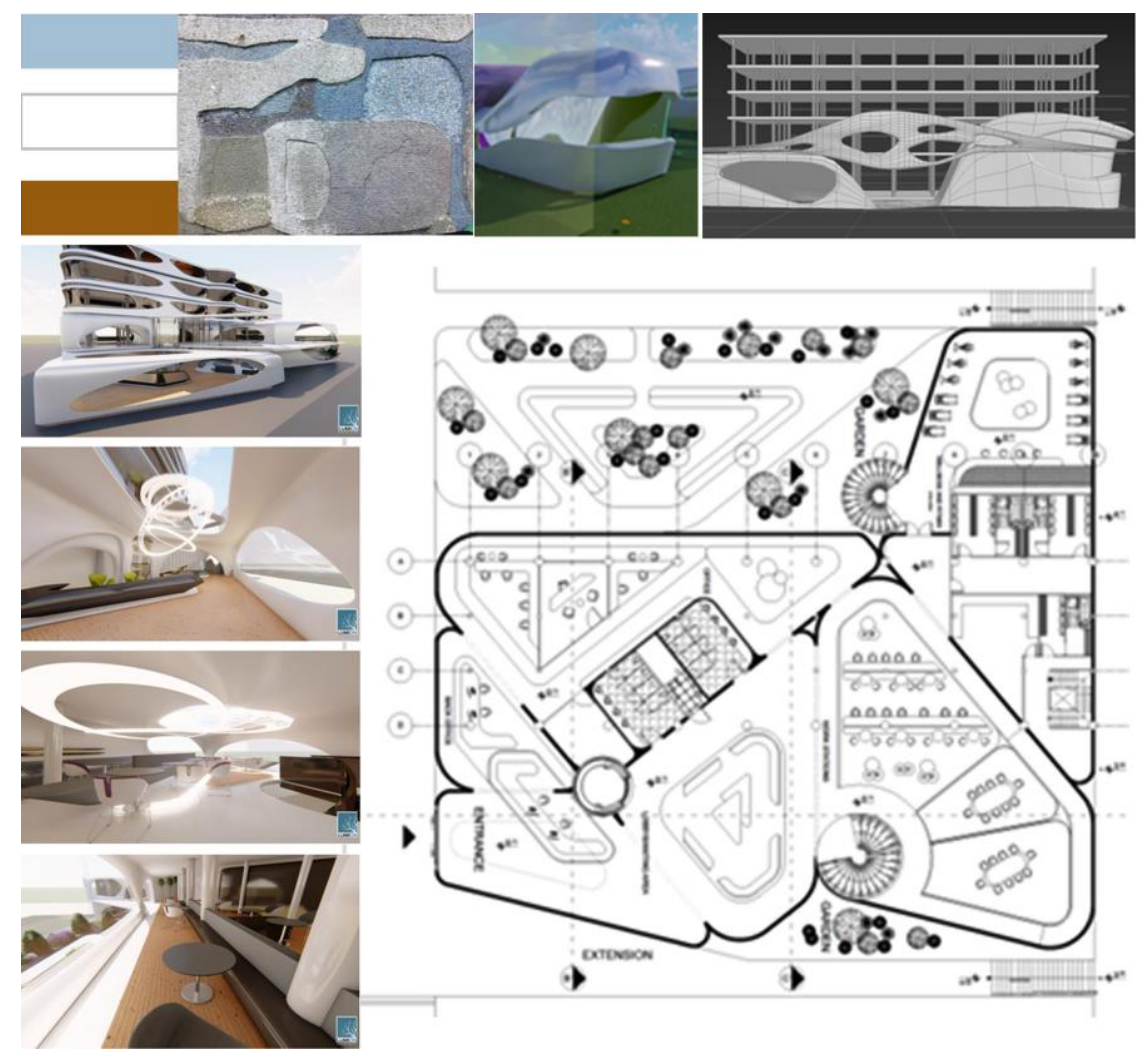

Figure 25. Begüm Çetinkaya 
This continuity of the space flow constituted the spine of the project, and in a sense, represented his thematic approach grounded on the fundamentals of architectural promenade. The a-contextual decisions of Güngördü in search of futuristic approaches towards parametric design at historical sites, professionally disguised within the courtyard, provoked queries on the level of coherence to the fundamentals of architectural fabric. (Fig. 24)

Begüm Çetinkaya, on the other hand, accepted the abstract-geometric sgraffito wall painting of Adnan Turani, composed of overlapping rectangular and square forms with beveled corners as her source of inspiration. She replicated the sgraffito technique of Turani in her form-finding process and developed her parametric rhizomes as three-dimensional rectangular prisms or cubes with beveled corners, juxtaposing each other. She handled the plan layout within the framework of these juxtapositions. In a sense, the trapezoid forms of Çetinkaya masked the axiality of the existing structural system. Her excavations of apertures onto the trapezoids established the internal/external relationship, sometimes functioned as windows that allowed the infiltration of the natural light and sometimes as balconies that detached the existing building from the parametric façade. Refusing to diversify trapezoid rhizomes concerning functional shifts, Çetinkaya neutralized the interior furnishings for eliminating them to intensify the emphasis on the architectural shell. The rhizome interpretation of Çetinkaya based on trapezoid forms with various apertures consciously underscored the manifestation of prolific vistas through the architectural facade, capturing unique shots from the historical site. (Fig. 25)

Ezgisu Bozkurt derived her rhizomatic conception from the S-formed figures of Füreya Koral and interpreted S-shaped waves in the sections of her project. Rather than reflecting this geometry in the plan layout, she decided to utilize the wave formed design in $-\mathrm{y}$ dimension for adhering to the orthogonal column-beam system of the existing building. By playing with the tectonics of the ceilings-walls-floors, the wave-shaped linear elements, which were repeated hierarchically along the facade, connected interior and exterior spaces by penetrating the interiors as the structure of ceiling cladding or lighting fixtures in social spaces such as the restaurant, reception area, lobby, and spa. The interpretation of interior fittings and furniture within the scope of this continuity brought a consistent language to the project. Bozkurt materialized the $\mathrm{S}$ forms delimiting room facades as transparent openings, which changed color harmonious with room types, whereas articulated the parametric shell in the courtyard enclosing public functions such as reception and lobby as shifting solid walls, regardless of functional requirements. This project exemplified the transposition of a two-dimensional shape into the third dimension without compromising the complex demands of the program. (Fig. 26)

Ezgi Bıylklı, on the contrary, interpreted the circular waveforms of Füreya Koral as her rhizomes and reflected her helical composition depicting $\mathrm{S}$ form around a center to a dynamic architectural element which manifested itself as continuous triangular ramps rotating around a single center within the extension. The prism shell deliberately obscured the dynamism of inward connections yet harmoniously depicted its implications via the inclined transparency along the ramp. She continued to maintain this dynamic language in the design of the interior atmosphere, from the decision of the lighting fixtures and materials to the furniture selections. To create a futuristic atmosphere inside, Biyıklı preferred brighter materials and vibrant colors. 


\section{Gર'}

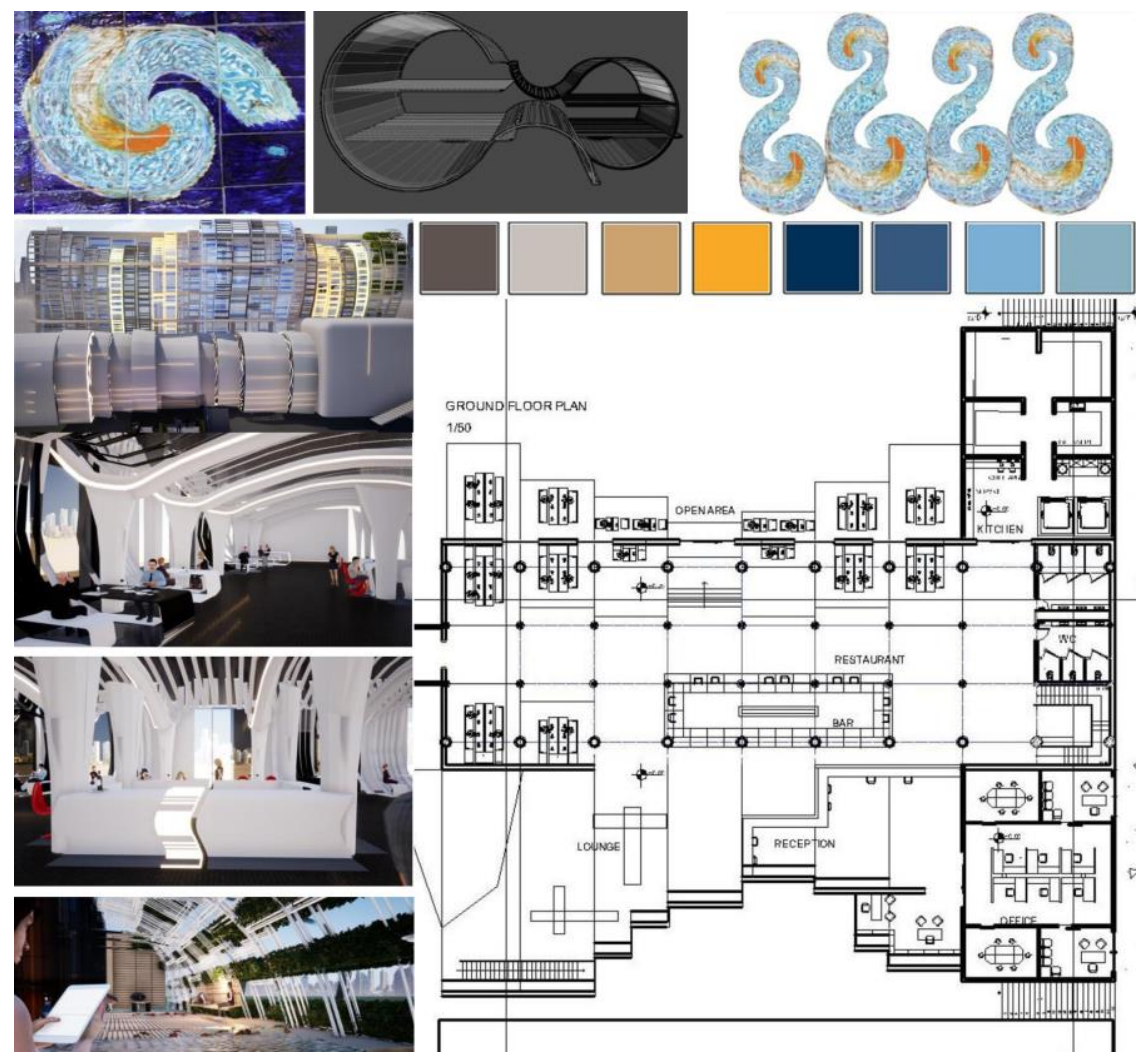

Figure 26. Ezgisu Bozkurt
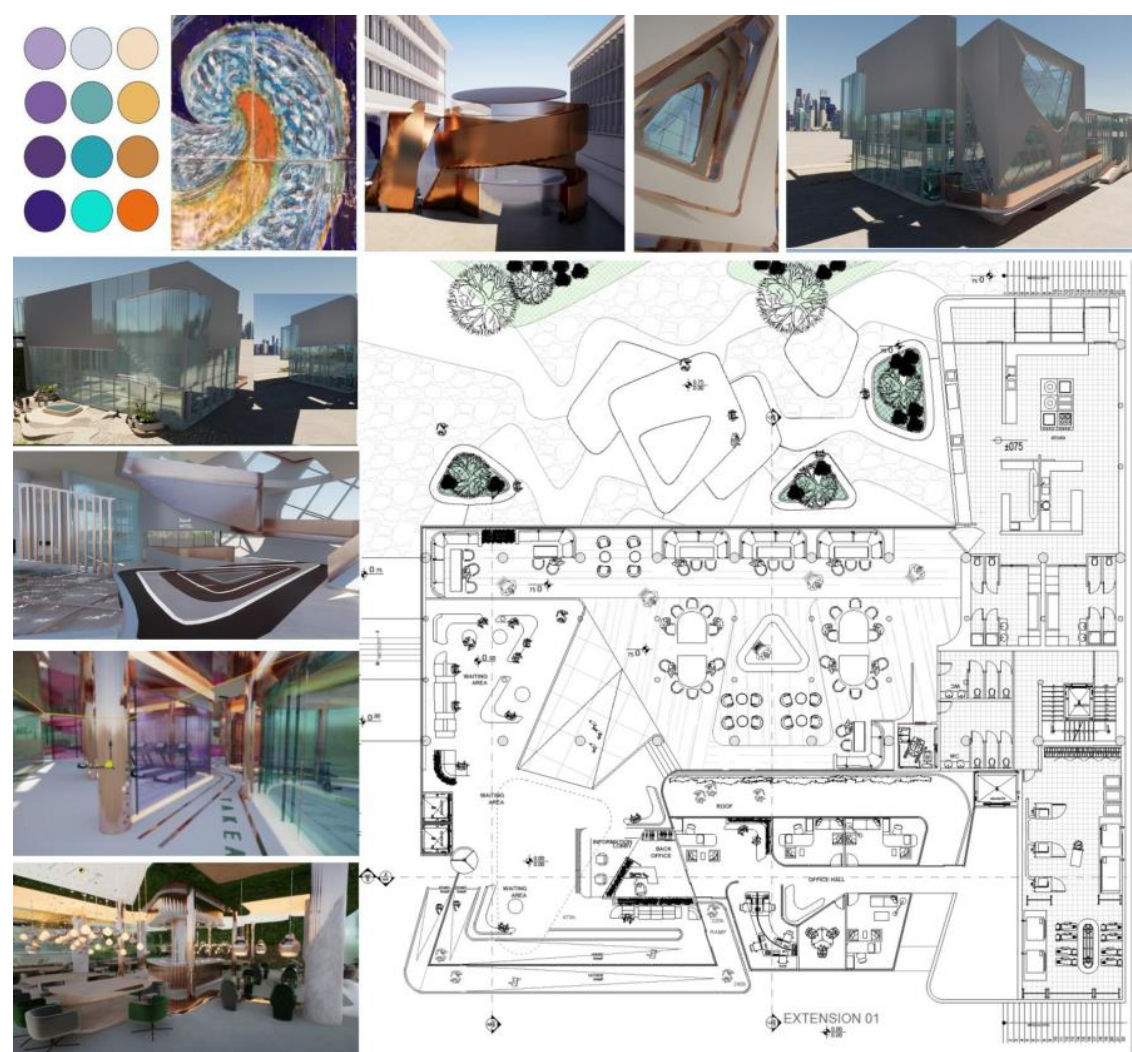

Figure 27. Ezgi Bıyıklı 


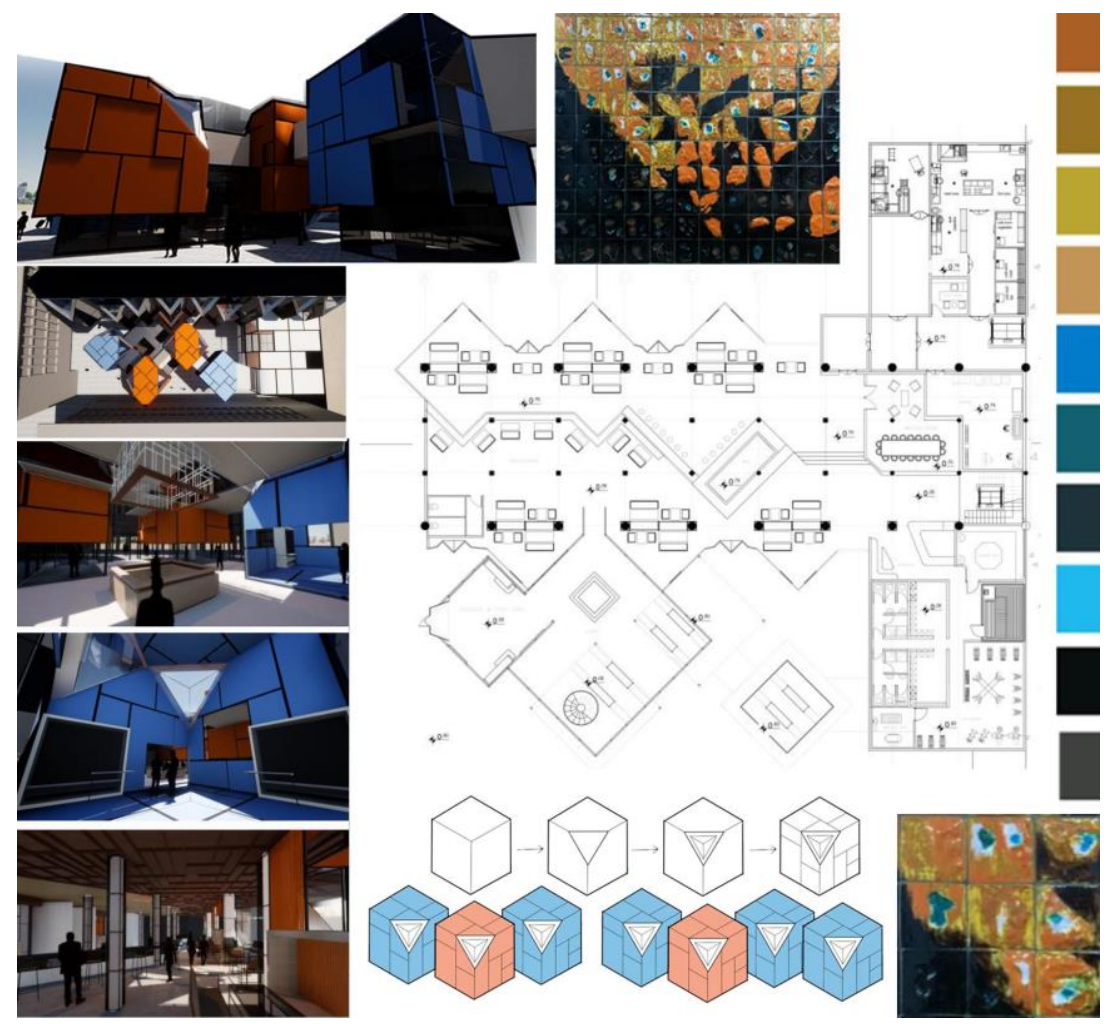

Figure 28. Arda Karataş

Even though her implementation of interior gardens in some public areas contradicted the artificiality of the modern, futuristic atmosphere, it represented her eco-friendly and humanistic approach. The rhizomatic conception of Biylkl1, based on the triangular ramps, which configured the interior circulation and the continuity of the space flow as an alternative interpretation of the architectural promenade, determined the design language of the interior space. (Fig. 27)

Arda Karataş, contrary to all his peers, interpreted the grid layout of the ceramic application in the abstract work of Füreya Koral as an inspiration for his rhizomatic conception. Karataş created his structural ceramic by juxtaposing or aligning rotated cube forms. These rotated cubes, placed at an angle of 45 degrees from the existing building as if rejecting the orthogonal order of the structural system, were subdivided with parametric tools to create a modulation on the facade. Karataş cut the corners of these cubes and utilized them as entrances/exits or as openings for natural lighting. Just as Koral obtained different figures on the grid base with the applications of color and glaze, the fenestrations at the corners of the cubes of Karatass created light and shadow plays in the interior space. Interpreting the subdivided cubes as double-skinned, Karataş analyzed the whole interior fittings within this interval. The built-in furniture designed between the skins fulfilled most of the spatial needs, except for rare incidences of freely floating movables inside. The parametric interpretation of the Mondrianesque grid, employed by Karataş, distinguished his form-finding strategy from other organic design solutions while glorifying the geometric order, refused the classical narratives dictated by the existing structure. (Fig. 28) 


\section{CONCLUSION}

Selecting an artwork and analyzing it as a source of inspiration, in the Studio 302 case, the ceramic artworks in the Anafartalar Bazaar established a pragmatic basis for the scope of experimenting with form-finding approaches in parametric design. Students' interpretations of the ceramic works became the most dominant input into the design project. Emulating the configuration patterns of the artists assisted students in developing creative strategies of form-finding and transforming their ideas into abstract configurations of architectural space, using computer-based design tools. They succeeded in converting existing figures of the artwork into architectural form "through variation" as in Ruskin's concept of changefulness. (Spuybroek, 2016, 5-10). Similarly, the digital strategies of grouping, unraveling, regrouping, multiplying resulted in the most precise articulation of artists' techniques used in the ceramic artworks. Although the inspiration of the artists seems to be different from the connotations of the students, these individual reinterpretations of the "variations" in the ceramic artworks uncovered a variety of digital design strategies, resulting in analogous design languages, yet experiencing diverse rhizomatic progress controlled by the functional changes. For instance, the formal analysis of student projects revealed that the students, except for Karataş and Çetinkaya, mostly preferred to reclassify decisions regarding artistic values of the ceramics in Anafartalar Bazaar and to utilize the circular and abstract figures as they associated parametric design notion with the organic forms of Zaha Hadid. Students of Studio 302 captured an experimental and expressionist design process by transforming the figurations on the ceramics first into form and then into a structure, just as the digital reproduction methodology, defined by Spuybroek (2016) referring to the concepts of "changefulness, variability, perpetual novelty" in Ruskin's 1853 book "The Nature of Gothic." During this process, the students overlooked the derivation of any parameters from environmental analyses or the existing building's architectural/cultural/historical value. Instead, they preferred to design futuristic oases in the historical center and experience the epitomes of contemporary approaches towards design. Even a jury member, a restoration architect, claimed that she appreciated the parametric design proposals of the students but preferred to overlook the restrictive criteria regarding the preservation of historic buildings in the context of this specific project. The metamorphosis of the rhizomes, on the other hand, was implemented through their unique dialogue with the proposed functions to convey an idiosyncratic design language reinforcing the dynamics of the interior space. As the dual contextual approach of Studio 302 prompted students to develop their rhizomatic conception concerning urban, architectural, and interior architectural factors, some projects might fail to satisfy the studio expectancy in this regard. Contrary to the studio expectancy, the re-functioning of Ulus Square Office Complex endowed the freedom to experience and create futuristic approaches, disregarding historical, social, or cultural templates, which may have provided a starting point, yet subdued as the project progressed, letting the rhizome take over the whole design. Studio 302 required the rhizomatic transformations on multiple tiers to enhance student awareness of the operative nature of diverse functional demands on the parametric form generation. This expectancy urged students to retain a coherent design mindset, a fundamental learning outcome for interior architecture studios. The semester turned into an adventure both for the students and the instructors. The students interpreted the rhizome concept of Deleuze and Guattari as a design strategy for apprehending the dialectical relationship of parametric form with functional requirements. In other respects, the instructors utilized the concept of rhizome as a teaching 
methodology for reconstructing the complex parameters of form generation, characterized by architectural and interior space dynamics.

To sum it up, Studio 302 aims to teach students to approach interior design from an integrated framework with related fields, provide a suitable platform to analyze the collected data, synthesize diverse information and ideas, and utilize them during the interior architectural design process. The syllabus, therefore, is formulated to furnish the students with the ability to sustain design notion from the beginning of the design process to the finalization of the construction process and to devise, select and effectively use the tools, techniques, and technologies related to design, drawing, software, and construction. Consequently, the future implications of this study could be founded on the codes of variations, creating rhizomatic metamorphosis in digital terms, with the help of visual programming languages, integrating the dynamic effects of structural forces and environmental factors in form-finding experiences. 


\section{Acknowledgements}

The syllabus formulation of Studio 302 belongs to the authors. The studio experience throughout the semester was shared with a group of instructors and research assistants, including Engin Demirok, Çetin Tünger, Serkan Mertyürek, İpek Yalçın, Burcu Eryllmaz, and Gülşah Doğan Karaman. We thank them for their valuable contributions and support.

\section{Conflict of Interest Statement}

There is no conflict of interest for conducting the research and/or for the preparation of the article.

\section{Financial Statement}

No financial support has been received for conducting the research and/or for the preparation of the article.

\section{Ethical Statement}

All procedures followed in accordance with the ethical standards.

\section{Author Contribution Statement}

\begin{tabular}{|l|l|l|}
\hline A. Idea, Concept & B. Study Design, Methodology & C. Literature Review \\
\hline D. Supervision & E. Material, Resource Supply & F. Data Collection, Processing \\
\hline G. Analyses, Interpretation & H. Writing Text & I. Critical Review \\
\hline
\end{tabular}

AUTHOR 1: A/B/C/F/G/H

AUTHOR 2: A/C/F/G/H 


\section{REFERENCES}

Akdoğan, Ö. G. (2018). City, Identity and Art: An Investigation on the Anafartalar Bazaar and the Public Art. Moment Dergi: Hacettepe Üniversitesi İletişim Fakültesi Kültürel Calısmalar Dergisi, 5(2), 383-425.

Allen, S. (2012, March). The Future That Is Now. Places Journal. Retrieved April 26, 2021, from https://doi.org/10.22269/120312

Asar, B. (2012). The Change and Spatial Analysis of Trade Buildings in Historic City Center of Ulus, Ankara. Selçuk Üniversitesi, Unpublished MS Thesis.

Bozdoğan, S., \& Akcan, E. (2013). Turkey: Modern Architectures in History. Reaktion Books.

Büyükkaragöz, T., \& Yayan, G. (June 2019). Importance of Füreya Koral in Contemporary Design. The Journal of Turk-Islam World Social Studies, 6(21), 73-86.

Can, Ö. C. (2018). Ceramic Murals in Public Spaces of Ankara. Master of Arts, Hacettepe University.

Cengizkan, A. (2019). Modernin Saati (2nd ed.). Arkadaş Kitabevi.

Cengizkan, A., \& Kılıçkıran, D. (2008, 2009). Yer'in Sesi: Ulus Isshani'nnn Söyledikleri (3rd ed.). Arkadaş Yayınevi.

Davis, D. (2013). A History of Parametric. Retrieved 4 5, 2014, from https://www.danieldavis.com/a-history-of-parametric/

Demirbaş, O. Ö., \& Demirkan, H. (2003, September). Focus on Architectural Design Process through Learning Styles. Design Studies, 24(5), 437 - 456. 10.1016/S0142-694X(03)00013-9

Ertemli, M. (Aralık 2018). Bir Kentin Bilinmeyen Hažinesi: Anafartalar Carşısı (1st ed.). Gece Akademi.

Frazer, J. (2016). Parametric Computation: History and Future. Architectural Design, 86, 18-23. Semantic Scholar. 10.1002/AD.2019

Güney, D. (2015, February). The Importance of Computer-aided Courses in Architectural Education. Procedia- Social and Social and Behavioral Sciences, 176, 757-765. Retrieved April 18, 2021, from https://www.researchgate.net/publication/273899314_The_Importance_of_Computeraided_Courses_in_Architectural_Education

İpek, A. R. (2020, June). Çağdaş Sanat Müzesi Olarak Anafartalar Çarşısı. İdil, (70), 985-1014. 10.7816/idil-09-70-07

Jabi, W. (2013). Parametric Design in Architecture. Laurance King Publishing.

Kambak, U. (2019). Art Practices on Belonging and City. Unpublished Master of Arts Thesis, Hacettepe University. http://hdl.handle.net/11655/5941 
Lynch, K. (1960). The Image of the City. MIT Press, Cambridge MA.

Rivka, O. (2017, September). Thinking difference: Theories and models of parametric design thinking. Design Studies, 52, 4 - 39.

Sárközi, R., Ivány, P., \& Széll, A. B. (2018). Methods of Teaching Parametric Design for Architectural Students. V. International Architectural Design Conference Archdesign '18, 25 - 29.

Schumacher, P. (2008). Parametricism as Style - Parametricist Manifesto [11th Architecture Biennale, Venice].

Schumacher, P. (2009, July/August). Parametricism - A New Global Style for Architecture and Urban Design. AD Architectural Design - Digital Cities, 79(4). http://www.patrikschumacher.com/

Sevim, S., \& Yeşilmen, N. (2017, Mayıs/Haziran). Füreya Koral: Ceramics in Turkish Grand National Assembly. SDÜ ART-E Güzel Sanatlar Fakültesi Sanat Dergisi, 10(19), 127-135.

Spuybroek, L. (2016). The sympathy of things: Ruskin and the ecology of design. Bloomsbury Publishing.

Şekerci, C., Yıldız, P. (2020). Parametrik Tasarım Süreci: İç Mimarlık Eğitim ve Pratiğinde Kullanım. Online Journal of Art and Design, 8(4), 298-307.

Tunçer, M. (2001). Ankara Şehri Merkez Gelişimi. T.C. Kültür Bakanlığı Yayınları.

Ulus Taribi Kent Merkezi Y Ykılması Planlanan Binalar: Anafartalar Çarşısı Baydar, Kırml, Şabbaz (1967). (n.d.). mimarlarodasiankara.org. Retrieved 09 20, 2020, from http:/ / www.mimarlarodasiankara.org/index.php?Did=1480

Ulus Taribi Kent Merkezi Y ikılması Planlanan Binalar: Ulus Meydani Isshan Bozkurt, Bolak, Beken (1954). (n.d.). mimarlarodasiankara.org. Retrieved 09 20, 2020, from http://www.mimarlarodasiankara.org/index.php?Did=1478

Ural, S.E., Akbay, S., \& Altay, B. (2017) Progression of color decision making in introductory design education. Color Research Application, 42, 849-860. https://doi.org/10.1002/col.22129

Woodbury, R. (2010). Elements of Parametric Design (1st ed.). Routledge. ISBN-10: 0415779871

Woodbury, R., Williamson, S., \& Beesley, P. (2011, August). Parametric Modelling as a Design Representation in Architecture: A Process Account. Proceedings of the Canadian Engineering Education Association (CEEA). https://www.researchgate.net/publication/228726452. 10.24908/pceea.v0i0.3827

Yılmaz, M. (2021, 02 02). Onay ç1karsa otel olacak. Hürriyet Ankara. https://www.hurriyet.com.tr/yerel-haberler/ankara/onay-cikarsa-otel-olacak-41730447 


\section{BIOGRAPHIES OF THE AUTHORS}

\section{Gülru MUTLU TUNCA}

Gülru Mutlu Tunca received her undergraduate degree from Faculty of Architecture (1997), Gazi University and her MArch (2001) and PhD degrees (2009) from METU. She has been working as an academic at Çankaya University since 2001 and currently acting as a full-time Instructor, Dr. at the Department of Interior Architecture. Architectural theory and criticism after the 1960s, Modern art and architecture, critical theory, Radical architecture, Italian design, architectural exhibitions, design and computer-based design are among her major of interests.

\section{Güler Ufuk DEMİRBAŞ}

G. Ufuk Demirbaş received her undergraduate (1995), MFA (1997) and PhD (2001) degrees from Department of Interior Architecture and Environmental Design, Bilkent University. She has been working as an academic at Çankaya University since 2001 and currently acting as a full-time Instructor, Dr. at the Department of Interior Architecture. Her major of interests include wayfinding, environmental psychology, ergonomics, interior architectural design and computer-based design. 